\title{
ІСТОРИЧНЕ ЗНАННЯ ТА ІСТОРИЧНА ДІЙСНІСТЬ: НА ЗАХИСТ «ВНУТРІШНЬОГО РЕАЛІЗМУ» ${ }^{*}$
}

\author{
Кріс Лоренц
}

Там де немае теорї̈ та активного мислення, там є тільки враження.

Гайден Вайm ${ }^{1}$

Якось одному фермеру потрапив до рук екземпляр «Критики чистого розуму» Канта. Він відкрив книгу і почав читати, але далеко не просунувся. Досить скоро він закрив книгу зі словами: «Мені б його проблеми!» ${ }^{2}$.

Цей анекдот був використаний німецьким істориком Крістіаном Маєром двадцять років тому, щоб змалювати складні взаємини між

* Переклад виконаний за виданням Lorenz, Chris. Historical Knowledge and Historical Reality: A Plea for «Internal Realism»// History and Theory: Contemporary Readings ed. B. Fay, P. Pomper, R. Vann. Oxford, 1998. - P. 342-376. На прохання автора переклад було звірено з більш пізньою німецькою публікацією статті: Ніstorisches Wissen und historische Wirklichkeit: Für einen «internen Realismus», в: Jens Schröter / Antje Eddelbüttel (Hgs.), Konstruktion von Wirklichkeit. Beiträge aus geschichtstheoretischer, philosophischer und theologischer Perspektive, Berlin/New York 2004, 65-106. Усі суттєві відмінності між початковим англійським оригіналом та німецьким перевиданням статті (що позначається далі як Historisches Wissen) указані в особливих примітках від перекладачів та у квадратних дужках у самому тексті.

${ }^{1}$ [White H. Figural Realism // Studies in the Mimesis Effect. - Baltimore and London, 1999. viii. - Епіграф і виноска додані в Historisches Wissen.]

${ }^{2}$ Meier C. Narrativität, Geschichte und die Sorgen des Historikers in Geschichte: Ereignis und Erzählung, ed. R. Koselleck and W. Stempel (Munich, 1973), 571-85. 
істориками і філософами, причому істориків він порівнював зі згаданим фермером. Жарт Маєра буде слугувати відправною точкою мого аналізу відносин між історією і філософією історії. Я збираюсь показати, що написання історії має набагато більш філософський характер, ніж це прийнято вважати серед істориків, і що визнання цього факту може розширити рамки історичних дискусій і покращити їхню якість. Всупереч таким філософам історії як Аткінсон, я захищатиму точку зору, згідно з якою філософія може виявитися корисною для істориків, оскільки здатність до філософського осмислення (philosophical insights) може покращити «заняття історією» ${ }^{3}$. Водночас, однак, я збираюсь показати, що це має місце тільки у тому випадку, коли філософи історії серйозно ставляться до проблем, якими переймаються професійні історики - а це означає, що суперечки істориків завжди повинні формувати вихідний матеріал для філософського аналізу, що і підкреслювали такі філософи, як Дрей та Мартін ${ }^{4}$.

Щоб прояснити суть своєї позиції, я проаналізую недавню дискусію серед німецьких істориків - знаменитий Historikerstreit ${ }^{*}$. При цьому я збираюсь пролити світло на взаємини між історією і філософією істоpiї, відстоюючи три тези. По-перше, всупереч широко розповсюдженій постмодерністській моді, я стверджую, що історики завжди претендують на знання реального минулого; і оскільки будь-яка претензія на знання передбачає претензію на істину, то обгрунтування претензії на істину повинне залишатись центральним як для історії, так і для філософії історії - нехай пробачать мене Рорті, Анкерсміт і постмодерністи $^{5}$. По-друге, я стверджую, що цей заклик повернутися до

${ }^{3}$ Atkinson R.F. Methodology: History and its Philosophy in Objectivity, Method and Point of View: Essays in the Philosophy of History. Ed. W. J. van der Dussen and L. Rubinoff (Leiden, 1991), 12-22.

${ }^{4}$ L. Rubinoff W. Dray and the Critique of Historical Thinking in Van der Dussen and Rubinoff, eds. Objectivity, 1-11; Martin R. The Past Within Us: An Empirical Approach to Philosophy of History (Princeton, 1989), 3-16.

* «Суперечка істориків» (нім.) - Тут і далі зірочками позначаються примітки перекладачів.

${ }^{5}$ Rorty R. Philosophy and the Mirror of Nature (Oxford, 1980); Ankersmit F.R. Historiography and Postmodernism // History and Theory, 28 (1989), 137-153; Zagorin $P$. Historiography and Postmodernism: Reconsiderations // History and Theory, 29 (1990), 263-274; Ankersmit F.R. Reply to Professor Zagorin // History and Theory, 29 (1990), 275-296. Далі література стосовно взаємозв'язку між історією і постмодернізмом: Herausforderungen durch die Postmoderne в Grundlagen und Methoden der Historiographiegeschichte, ed. W. Küttler et al. (Frankfurt, 1993), 17-97; Stone History and Post-modernism // Past and Present, 131 (1991), 217-18; Joyce P., Kelly C. History and Post-modernism // Past and Present, 133 (1991), 204-213; Spiegel G. History and Post-modernism // Past and Present, 135 (1992), 189-208; Caplan J. Postmoderni- 
джастифікаціонізму в філософії історії передбачає реалізм по відношенню до минулого як з боку істориків, так і з боку філософів історії. Таким чином, викриття наївного реалізму - або об'єктивізму, як його часто називають, - зовсім не означає відмови від реалізму в цілому, а також не потребує прийняття ідеалізму (як думають деякі послідов-

sm, Poststructuralism and Deconstruction: Notes for Historians // Central European History, 22 (1989), 260-78.

[У Historisches Wissen частина цього речення після тире змінена таким чином: «всупереч алергії на істину з боку постмодернізму». Замість відтвореної вище примітки англійського оригіналу до цих слів надається наступна нова розлога примітка: «Що стосується значення поняття постмодернізму, то я поділяю точку зору Вельша, як вона викладена в його книзі Unsere postmoderne Moderne, Berlin 1997, 1-8. Згідно Вельшу, постмодерністську позицію об'єднує (1) «недовіра до історичних метанаративів», таких як лібералізм, марксизм і модернізм, що приводить до фундаментальної відмови від будь-якої матеріальної філософії історії та до фундаментальної відмови від редукції множинності до єдності, тобто до антиредукціонізму та антиунітаризму; (2) відмова від уявлення, що існує незалежна від поглядів суб'єкта дійсність, тобто антиоб'єктивізм. Внаслідок цього антиоб'єктивізму відкидається будь-яка дискусія про дійсність, що не залежить від їі символічних, зокрема, мовних репрезентацій. Я погоджуюсь і з розрізненням, яке Вельш проводить між цікавими і вульгарними варіантами постмодерністського мислення. Що стосується постмодернізму в історичній науці, то тут корисний аналіз «постмодерністського виклику», здійснений Рюдигером Графом у статті Interpretation, Truth, and Past Reality. Donald Davidson meets history // Rethinking History 7 (2003), 3, 387-402, особливо, 388-390. Граф зводить постмодерністський погляд на історію до чотирьох основних уявлень: (1) множинність описів, тобто уявлення, що про одну і ту саму сукупність подій чи фактів можна розповісти багато різних історій, і що «тому» факти не детермінують інтерпретації і «тому» немає жодної різниці між істинними і хибними інтерпретаціями; (2) текстуалізація історії, тобто уявлення, що історик має справу тільки з текстами; оскільки історик не має безпосереднього доступу до самого минулого, то істина історичних повідомлень не може бути установлена в сенсі кореспонденції: історичні тексти можна порівнювати тільки з іншими текстами, а не з самим минулим; (3) дереференціалізація мови, тобто уявлення, що слова отримують своє значення через їх співвіднесення з іншими словами, а не через їх референцію до позамовної дійсності (це уявлення, як правило, пов'язують з де Соссюром і Деррідою): «тому» історіографічні тексти не можуть відноситися до минулого, і не можуть бути істинними у тому сенсі, що вони кореспондують з минулим; (4) наративність, тобто уявлення, що наративи (Erzählungen) мають свою власну логіку, котра не залежить від висловлювань про факти, які до них входять. «Тому» наративи не можуть бути істинними чи неістинними. Детальніше див. в Conrad Chr./ Kessel M. (Hg.), Geschichte schreiben in der Postmoderne. Beiträge zur aktuellen Diskussion, Stuttgart 1994; Jenkins K. (Hg.), The Postmodern History Reader, London 1997. Критичний розгляд див. Zagorin P. Historiography and Postmodernism. Reconsiderations // History and Theory, 29 (1990), 263-274; Його ж History, the referent and narrative // History and Theory, 38 (1999), 1-24; Від укладача, «You got your history, I got mine». Some reflections on truth and objectivity in history, Östereichische Zeitschrift für Geschichtswissenschaften 10, 4 (1999) 563-584.] 
ники Колінгвуда) або естетизму - чи інших різновидів релятивізму ${ }^{6}$. По-третє, я стверджую, що той різновид реалізму, який я розвиваю т.зв. «внутрішній реалізм», - дозволяе по-новому висвітлити класичну проблему фактів і цінностей, котра давно турбує як істориків, так і філософів історії. Зазначений аналіз призводить до висновку - до якого прийшли також Юрген Габермас, Юрген Кока та Йорн Рюзен, - що нормативний вимір історії неможливо елімінувати, а тому він потребує раціонального обгрунтування ${ }^{7}$.

\section{Historikerstreit}

Historikerstreit досяг свого апогею у 1986 та в 1987 році ${ }^{8}$. Його центральною темою було місце «Третього Рейху» в історії Німеччини тема, широко обговорювана німецькими істориками ще з кінця 1960-х pp. Я обрав цю дискусію за приклад через її вибуховий характер. 3 цієї ж причини Historikerstreit може бути проаналізований як свого роду колективна «обмовка за Фрейдом» історичної професії, що викриває такі аспекти, які зазвичай залишаються прихованими у «нормальних» дискусіях. [Спадкоємність з новітніми дискусіями про німців як жертв війни (deutschen Opferdiskurs) і у 2004 р. свідчить, що вибір цього прикладу був дуже вдалим ${ }^{9}$.] Я зосереджу увагу на основних сторонах, що

\footnotetext{
${ }^{6}$ Як приклад міркувань у руслі ідей Колінгвуда див.: Van der Dussen W.J., Filosofie van de geschiedenis: Een inleiding (Muiderberg, 1986), 144-79; про проблему релятивізму див.: Bernstein R. Beyond Objectivism and Relativism (Oxford, 1983), $1-16$.

7 Для порівняння див.: Lorenz $C$. De constructie van het verleden (Meppel/Amsterdam, 1990), 255-282. Що стосується «внутрішнього реалізму» див.: Putnam H. Reason, Truth and History (Cambridge, 1981), 49.

8 Література з цієї дискусії дуже чисельна. Загальний огляд і аналіз див.: Evans $R$. In Hitler's Shadow: West German Historians and the Attempt to Escape from the Nazi Past (London, 1989) та Maier C. The Unmasterable Past: History, Holocaust and German National Identity (Cambridge, Mass., 1988). Оригінальні статті, які власне утворюють цю дискусію, розміщені у збірнику Historikerstreit. Die Dokumentation der Kontroverse um die Einzigfartigkeit der nationalsozialistischen Judenvernichtung (Munich, 1987), на який я у подальшому буду посилатися як на Historikerstreit.

${ }^{9}$ [Я маю на увазі дебати і публікації про німців як жертв війни, котрі розпочалися після опублікування творів Бернхарда Шлінки «Читець», Гюнтера Грасса «Траєкторія краба» та Йорга Фрідріха «Пожежа» і «Згарище». Про розвиток дискусї про німців як жертв війни див. мою статтю Bordercrossings. Some reflections on the role of German historians in recent public debates on Nazi history / Michman D. (Hg.), Remembering the Holocaust in Germany 1945-2000. German Strategies and Jewish responses (New York, 2002), 59-95.]
} 
сперечаються, і свідомо схематизую полеміку у вигляді суперечки між двома групами. Одна група концентрується навколо Ернста Нольте й Андреаса Гілльрубера. Іншу групу складають їхні критики на чолі з Юргеном Габермасом, Гансом Моммзеном і Мартіном Брошатом. Можна показати, що ці історики обгрунтовували свої претензії на знання, апелюючи до «фактів», «дійсності» та «істини»; водночас виявляється, що вони намагаються підірвати претензії на знання з боку опонентів, викриваючи їх як «оціночні судження».

Historikerstreit розпочався зі статті філософа і соціолога Габермаса, опублікованої у газеті «Die Zeit» ${ }^{10}$. У ній Габермас критикував апологетичні тенденції нових трактувань націонал-соціалізму в роботах західнонімецьких істориків. Нольте і Гілльрубер - обидва відомі спеціалісти - були його найбільш значними мішенями. У своїх останніх роботах Нольте запропонував застосувати до історії Третього Рейху нову перспективу бачення ${ }^{11}$. Він вважав це необхідним, оскільки традиційне зображення «Третього Рейху» як абсолютної імперії зла, на його думку, застаріло. Згідно Нольте, історики, котрі дотримуються такого уявлення, використовують штамп, введений нацистами: приписування колективної вини. Єдина відмінність полягає тут у тому, що колективна вина приписується німцям замість євреїв. Негативний імідж «Третього Рейху», вважає Нольте, не лише змушує мислити у чорно-білих тонах, але й породжує «націоналізм навпаки». Це заважає розвитку наукової історії, оскільки історичне розуміння можливе лише за умови бачення різних відтінків сірого.

Нольте навів два приклади запропонованої ним нової перспективи бачення, в контексті якої слід інтерпретувати нацистську Німеччину. Націонал-соціалізм у цілому та нацистські злочини по відношенню до євреїв зокрема не повинні розглядатися лише в рамках німецької історії; замість національної необхідно залучити порівняльно-европейську або навіть глобальну перспективу бачення. Це обгрунтовується тим, що історія двадцятого століття набула характеру глобальної історії у точному сенсі цього слова; тому національна історія вказаного періоду була б повним анахронізмом. Наднаціональний характер історичної

\footnotetext{
${ }^{10}$ Habermas J. Eine Art Schadensabwicklung: Die apologetischen Tendenzen in der deutschen Zeitgeschichtsschreibung в Historikerstreit, 62-77.

${ }^{11}$ Nolte E. Zwischen Geschichtslegende und Revisionismus? Das Dritte Reich im Blickwinkel des Jahres 1980 та Vergangenheit die nicht vergehen will в Historikerstreit, 13-36 та 39-48. Про захист ним своєї позиції й коментарі до цієї дискусії див.: Nolte E. Das Vergehen der Vergangenheit: Antwort auf meine Kritiker im sogenannten Historikerstreit (Berlin, 1987).
} 
дійсності двадцятого століття буквально вимагає від істориків наднаціональної перспективи бачення. Відповідно, історики не повинні більше ставитися до Гітлера як до невдалої імітації Бісмарка, але скоріше у ньому слід вбачати європейського «Анти-Леніна». Історики, не здатні зрозуміти цього елементарного факту, жорстоко помиляються.

Аргументуючи таким чином, Нольте наполягає на тому, щоб злочини нацистів по відношенню до євреїв розглядалися у світлі інших масових вбивств двадцятого століття, починаючи з турецького геноциду вірменів, масових вбивств під час революції у Росії та після неї, а також нещодавніх кровопролить у В'єтнамі, Камбоджі й Афганістані. Згідно з Нольте, всі ці криваві розправи мають бути осмисленими в контексті процесів викорінення певних соціальних і культурних форм, а також у контексті ідеологій, створених для забезпечення цих процесів. Вказаний процес викорінення розглядається Нольте як один із наслідків процесу модернізації, що розпочався разом із промисловою революцією.

У центрі ідеологій, про які йдеться, міститься ідея, що фізична ліквідація якоїсь конкретної соціальної групи призведе до вирішення проблем «нашого часу», оскільки така ліквідація є необхідною умовою існування утопії. Нольте стверджував, що найбільш впливовими з цих «утопічних фантазій про повне винищення» $є$ марксизм і націоналсоціалізм. Їхній вплив обумовлювався тим фактом, що ці ідеології були взяті на озброєння успішними політичними рухами й перетворилися на державні ідеології: у Росії після 1917 року, а в Італії та Німеччині після 1922 й 1933 років відповідно. У Росії і Німеччині такі «фантазії про повне винищення» пізніше були втілені у життя.

Згідно з Нольте, ці події були взаємопов'язані, оскільки німецька практика повного винищення була «викликана» російським прикладом. Очевидно, що остання теза є найбільш суперечливою складовою нової перспективи бачення німецької історії, запропонованої Нольте. Він вкладає вказаний причинний взаємозв'язок [між «Гулагом» та «Аушвіцом»], котрий тлумачиться ним як необхідна, але недостатня умова, у свідомість Гітлера та його найближчого оточення. Саме загроза російської революції і страх перед винищенням подібним до того, яке здійснювалося більшовизмом по відношенню до російської буржуазіі, і спонукали Гітлера до створення Аушвіца, говорить Нольте. У свідомості націонал-соціалістів більшовизм був єврейським винаходом, а в Радянській державі панували євреї. 3 цієї причини Гітлер ототожнював боротьбу проти більшовизму з боротьбою проти євреїв, що мало для останніх фатальні наслідки. На думку Нольте, антисемітизм 
нацистів необхідно розглядати, таким чином, як історично зрозумілу трансформацію їхнього «легітимного» страху перед більшовизмом. Традиційний антисемітизм не відігравав у цих подіях взагалі жодної ролі.

Андреас Гілльрубер, незалежно від Нольте, також розробив нову перспективу бачення історії нацистської Німеччини ${ }^{12}$. Подібно до Нольте, він пропонує підійти до розгляду цього епізоду зі сходу i, як і Нольте, критикує інших за обмеженість перспективи бачення ${ }^{13}$. Ця «недостатність» вказує на їхню сліпоту по відношенню до двох національних катастроф Другої Світової війни та їхнього взаємозв'язку - катастрофи європейських євреїв і катастрофи німецького народу. Остання полягає у вигнанні дванадцяти мільйонів німців Східної і Центральної Європи в 1944-1945 рр. у зв'язку з приєднанням їхньої колишньої батьківщини до Росії та Польщі і поділом Німеччини. Згідно з Гілльгрубером, історики до сих пір так і не пояснили взаємозв'язок між цими двома катастрофами у правильній загальноєвропейській перспективі. Вони припускають наявність прямої залежності між німецькою та єврейською катастрофами, пояснюючи першу як покарання союзників за другу. Але така точка зору є неправильною, тому що у той час, коли держави антигітлерівської коаліції розробляли плани стосовно устрою Німеччини після її поразки, про єврейську катастрофу ще не було відомо. Тому політика союзників щодо післявоєнної Німеччини не може бути пов'язана з німецькими злочинами проти єврейського народу, а має відноситись на рахунок так званого «прусського стереотипу». Суть цього стереотипу полягає в ідеї про існування «німецької загрози» для Європи, а також у тому, що ця загроза зникне лише разом із Прусською мілітаристською державою (і самим її серцем, розташованим на схід від Ельби). Таким чином, єврейська і німецька катастрофи причинно ніяк не пов'язані.

Однак, згідно з Гілль'рубером, взаємозв'язок між двома катастрофами все ж таки мав місце, оскільки вони обидві можуть бути поясне-

${ }^{12}$ Hillgruber A. Zweierlei Untergang: Die Zerschlagung des Deutschen Reiches und das Ende des europäischen Judentums (Berlin, 1986).

${ }^{13}$ [Нещодавно Філіп Тер переконливо показав у своїй статті Beyond the nation. The relational basis of a comparative history of German and Europe, Central European History, 36 (2003), 45-73, що насправді німецькі історики, навіть після 1945 року, у незначній мірі писали німецьку історію «зі східної точки зору», не кажучи вже про «європейську точку зору». На думку Тера, ці історики ретроспективно i «неісторично» накладали «західну орієнтацію» Федеративної республіки на всю німецьку історію Нового часу. Проте, аналіз Тера немає жодного відношення до апологетичних аргументів Нольте і Гілльгрубера.] 
ні за допомогою певного прихованого фактору. Ця прихована причина коріниться у політиці депортацій і ліквідації цілих народностей, що випливала із розробленої у двадцятому столітті ідеї «етнічної чистки». Сталіна і Гітлера можна виділити з-поміж інших масових убивць лише за тією радикальністю, з якою вони впроваджували цю ідею у життя. Єврейська катастрофа є її найбільш помітним результатом, при цьому німецька катастрофа - як наслідок цієї ж ідеї - відійшла на задній план. Проте, вони відносяться до одного і того ж самого історичного контексту.

Як і у Нольте, нова перспектива бачення історії Гілльгрубера передбачає безпосередній взаємозв'язок між німецькою політикою повного винищення і загальною європейсъкою історією. Це не означає, що Гіллырубер повністю ігнорує той факт, що без нацистської Німеччини Аушвіц був би неможливим i, відповідно, поразка Німеччини була вкрай бажаною. Ця проблема представлена як трагічна дилема німецької армії, дилема без будь-якого сподівання на вирішення [- дилема, котра передбачає, як саме собою зрозуміле, розмежування «чистого» Вермахту і злочинних нацистів $\left.{ }^{14}\right]$. Захищаючи німецьке населення від наступаючої Червоної армії, Вермахт мимоволі надав нацистам можливість продовжувати їхню політику винищення в концтаборах за лінією фронту. Єдиний шлях, наявний у німецьких істориків для того, щоб усвідомити цю трагедію, полягає в уявному перенесенні себе в цю ситуацію. Згідно з Гілльрубером, ключ до історичного розуміння полягає у тому, щоб поглянути на цю ситуацію очима німецької армії і описати її з точки зору такого підходу, тому що саме так чинив німецький народ. Тому для історика Східного фронту «реалістичним» є лише підхід з точки зору Вермахту. Як і Нольте, Гілльгрубер намагається, таким чином, узаконити свою нову перспективу бачення, апелюючи до історичної дійсності.

Ці дві перспективи бачення історії, підсумовані таким чином, спричинили Historikerstreit. У ході цієї дискусії німецькі історики розкололися на два табори. Історики, які симпатизували лівим поглядам того чи іншого штибу, схилялися до підтримки критики, висловленої Габермасом. Їхні статті друкувалися головним чином у лівоцентристському ліберальному щотижневику «Die Zeit». Більш консервативно налаштовані історики підтримували Нольте і Гіллырубера, намагаючись

14 [Після організації виставки «Війна на винищення. Злочини Вермахту у 19411944 pp.» і тих дебатів, котрі ㄲï супроводжували - тобто з 1995 р. - це розмежування, яке серед спеціалістів вже давно вважається застарілим, є досить проблематичним. У цьому сенсі Historikerstreit також вже став «історією».] 
захистити їх від критики Габермаса та інших. Їхні статті з'являлися переважно у консервативній щоденній газеті «Frankfurter Allgemeine Zeitung».

Ця полеміка являє собою воістину постмодерністську виставу. Твердий грунт, на який зазвичай спираються історики, практично повністю перетворюється на болото релятивізму і суб'єктивізму. Всі стрижні «нормальної» історичної науки - такі як джерела, факти та історичний метод - безслідно тонуть у цьому болоті. Навіть питання про те, а чи була між прихильниками двох таборів дискусія у справжньому сенсі цього слова, здається неоднозначним: захисники Нольте і Гілльрубера просто заперечують наявність суперечки серед істориків, говорячи про «так званий Historikerstreit» або про спрямовану проти них ганебну «політичну і моральну кампанію», або про «полеміку Габермаса» ${ }^{15}$. Фразу «ваша дійсність відрізняється від моєї» ймовірно можна назвати єдиним беззаперечним твердженням у всій цій дискусії.

Свідченням на користь цього слугує та обставина, що фактуальні твердження однієї сторони у цій дискусії не визнаються такими іншою стороною і часто викриваються як політичні «оціночні судження». Як приклад можна навести те, в який спосіб характеризується винищення євреїв нацистською Німеччиною. Критики Нольте і Гілльгрубера вважають псевдопромисловий характер процесу винищення європейських євреїв нацистами єдиним у своєму роді історичним фактом, що відрізняє ці події від інших масових розправ у світовій історії. Ця точка зору засновується на тому міркуванні, що нацисти навмисно використовували апарат «цивілізованої» держави з метою досягнення своєї кровавої мети, у той час як інші масові погроми відбувалися в хаотичному контексті війни або ж громадянської війни. Помістити Аушвіц у порівняльну перспективу європейської чи світової історії - як це роблять Нольте і Гілльгрубер - означає стерти тим самим найважливішу фактичну особливість націонал-соціалізму: його унікально деструктивний характер. Переписуючи німецьку історію як загальноєвропейську історію, історики прагнуть не до нових наукових прозрінь, а лише зловживають порівняльною перспективою, переслідуючи політичну мету витіснення у підсвідомість цього травмуючого історичного факту $^{16}$.

${ }^{15}$ Nolte Vergehen der Vergangenheit, 13-68; Hillgruber A. Jürgen Habermas, KarlHeinz Janssen und die Aufklärung Anno 1986 в Historikerstreit, 331-52; Geiss I. Die Habermas-Kontroverse: Ein deutscher Streit (Berlin, 1988).

${ }^{16}$ Wehler H.-U. Entsorgung der deutschen Vergangenheit? Ein polemischer Essay 
Захисники Нольте - такі як Йохам Фест і Клаус Гільдебранд - взагалі не вважають цей унікальний характер винищення, розв'язаного націонал-соціалізмом, історичним фактом; замість цього вони відносять його до запізнілого прояву німецької «Herrenvolkgesinnung» ${ }^{*}$, оскільки остання зводиться до твердження, що німці перевершують усіх інших, навіть якщо для ствердження цього потрібно вбивати цивільне населення ${ }^{17}$.

Ще один ключовий факт для критично налаштованих істориків, таких як Ганс Моммзен і Мартін Брошат, полягає у тому, що Німеччина не була монолітною одноосібною диктатурою; така держава не могла б функціонувати без активного сприяння консервативної торгової і промислової еліт, армії та бюрократії. 3 їхньої точки зору, ключовий факт відносно Третього Рейху - не наявність ідейного фанатика, а те, що цей фанатик очолив державу і більше дванадцяти років користувався палкою підтримкою еліти і державного апарату у здійсненні своєї злочинної політики. Вони вважають, що каузальна редукція нацистських злочинів до умонастрою Гітлера і його страху перед більшовизмом являє собою політично мотивовану спробу затушувати ключову роль цих консервативних «Funktionseliten» ${ }^{*}$ Третього Рейху - i, тим самим, перенести відповідальність з Третього Рейху на Комунізм ${ }^{18}$.

Нольте, як і слід було очікувати, дотримується іншої точки зору. Він не визнає історичним фактом співробітництво між консервативними елітами й Гітлером, оскільки (майже) всі німці об'єдналися під час війни - і це так само вірно як по відношенню до раніше лівацьки налаштованих робітників, так і по відношенню до традиційно правих еліт. Приписування особливої відповідальності цим елітам призводить до того, що вина покладається виключно на ці групи, в дусі проти-

zum Historikerstreit (Munich, 1988), 16-17; Maier The Unmasterable Past, 83-4; Evans Hitler's Shadow, 175.

* Ідеологія пануючої раси (нім.).

${ }^{17}$ Fest J. Die geschuldete Erinnerung: Zur Kontroverse über die Unvergleichbarkeit der nationalsozialistischen Massenverbrechen в Historikerstreit, 104-113; Hildebrand K. Das Zeitalter der Tyrannen in Historikerstreit, 91.

* Функціональні еліти (нім.).

${ }^{18}$ Mommsen H. Suche nach der 'verlorenen Geschichte'? Bemerkungen zum historischen Selbstverständnis der Bundesrepublik та Neues Geschichtsbewusstsein und Relativierung des Nationalsozialismus в Historikerstreit, 156-174 i 174-189; Broszat M. Wo sich die Geister scheiden: Die Beschwörung der Geschichte taugt nicht als Religionsersatz в Historikerstreit, 189-196; Winkler H.-A. Auf ewig in Hitlers Schatten? Zum Streit über das Geschichtsbild der Deutschen в Historikerstreit, 256-264; Mommsen W.J. Weder Leugnen noch Vergessen befreit von der Vergangenheit: Die Harmonisierung des Geschichtsbildes gefährdet die Freiheit в Historikerstreit, 300-332. 
ставлення «добрих» $\mathrm{i}$ «поганих». Нольте стверджує, що насправді ці історики експлуатують тему Третього Рейху як інструмент для своєї критики сучасного суспільства з лівих політичних позицій ${ }^{19}$.

У свою чергу, критики Нольте і Гілльрубера заперечують, що їхні ключові факти дійсно є фактами. Оскільки факти - це стани справ, що можуть бути викладені в істинних твердженнях, то претензї на фактологічність відносяться як до описового, так і до пояснювального рівнів наративів ${ }^{20}$.

Фактуальне твердження Нольте, що націонал-соціалізм можна каузальним чином вивести із більшовизму, відкидається як політичний обман. Фактуальне твердження Гілльгрубера про каузальний зв'язок єврейської катастрофи із «прихованим фактором», характерним для європейської історії в цілому, а не лише для нацистської Німеччини, зустрічає таке ж різке неприйняття. Їхні критики підкреслюють безпосередній зв'язок між закликом Нольте і Гілльгрубера до «наукового оновлення» та консервативним політичним закликом 1980-х рр. у Федеративній Республіці «вийти врешті-решт із тіні Гітлера» ${ }^{21}$. Політичною метою цих «нових перспектив бачення» німецької історії вважається формування самосвідомості німців як «нормальної нацї̈.

Звичайно ж, Нольте і Гілльгрубер дещо страждають від усіх цих «непорозумінь» $з$ приводу своїх, як вони вважають, шляхетних і суто наукових устремлінь. Намагання приписати їм апологетичний намір, неспростовно доводить, з їхньої точки зору, зашореність їхніх опонентів своєю лівою ідеологією. Ці шори заважають їм визнати безсторонні істини, особливо якщо ці істини стверджують люди 3 «неправильними», тобто правими політичними поглядами. Наука, однак, вимагає

${ }^{19}$ Nolte Vergehen der Vergangenheit, 57, 88-89; Nolte Geschichtslegende, 23; Nolte Vergangenheit, 41.

${ }^{20}$ Див.: Hamlyn D.W. The Theory of Knowledge (London, 1970), 136-142 щодо взаємозв'язку між фактами та істиною, особливо с. 137: «Вірно, що факт являє собою те, що викладено за допомогою істинного твердження, але із цього не слідує, що це одне й те саме; буде також невірним сказати, що факт - це лише те, що викладено за допомогою істинного твердження. Оскільки можна було б сказати, що факти не існують, поки не сформульовано висловлювання, яке виявиться істинним, у той час як зворотне, вочевидь, виконується, існують безліч фактів, які ніколи не були викладені й ніколи не будуть».

${ }^{21}$ Ця відома фраза була висловлена покійним консервативним політиком ХСС Францем Йосифом Штраусом. 3 приводу політичного контексту полеміки див.: Ist der Nationalsozialismus Geschichte? Zu Historisierung und Historikerstreit, ed. D. Diner (Frankfurt am Main, 1987) i Streit ums Geschichtsbild: Die «Historikerdebatte». Dokumentation, Darstellung und Kritik, ed. R. Kühnl (Cologne, 1987), особливо с. 200292. 
«аполітичної» позиції і визнання істини поза будь-якою залежністю від політичного забарвлення того, хто її стверджує. Оскільки справжня наука просто не може існувати, якщо залишаються «заборонені» питання ${ }^{22}$.

Підсумовуючи, навряд чи розходження між двома сторонами цієї дискусії могли б бути більш фундаментальними, оскільки вони торкалися як описових тверджень про факти, так і пояснювальних тверджень про взаємозв'язок між фактами. Відмінність між фактуальними твердженнями та оціночними судженнями постійно опиняється в центрі обговорень, обговорень, які переходять у найсильніші суперечки.

\section{2 Внутрішній реалізм}

Філософ історії може по-різному реагувати на емоційні дискусії на кшталт Historikerstreit. Перший шлях - реагувати як Нольте і Гілльгрубер: у цьому випадку робиться висновок, що згадана суперечка $\epsilon$ не науковою, а політичною. Цей висновок передбачає, що наука - на відміну від політики - це заснована на фактах дискусія, в якій сторони, що сперечаються, претендують на істину, а такий різновид суперечки завершується - принаймні в перспективі, - коли досягається консенсус. Цей консенсус з приводу фактів складає основу наукового знання. Такого роду реакцію і такий погляд на наукове знання можна назвати об'єктивістськими, тому що вони базуються на класичному ідеалі об'єктивного історичного знання ${ }^{23} .3$ цієї точки зору, історичний метод розглядається як фільтр між істиною та не-істиною і відповідно як основа згоди у середині наукової спільноти. Часті апеляції Нольте і ГілльҢрубера до «фактів», «джерел», «істини» й «науки» свідчать про

${ }^{22}$ Nolte Vergangenheit, 45 i Vergehen der Vergangenheit, 91; Hillgruber Frageverbot, $232-238$.

${ }^{23}$ Про визначення традиційного об'єктивізму в історії див.: Novick P. That Noble Dream: The «Objectivity Question» and the American Historical Profession (Cambridge, 1988), 1-2. Про філософські передумови об'єктивізму див.: Bernstein Beyond Objectivism and Relativism, 8-9, 19. [Той різновид об'єктивізму, який пояснює розбіжності в науці впливом «політики» та «оціночних суджень», вже давно легітимізований такими класичними соціологами науки, як Роберт Мертон та Дж. Бен-Давід. Огляд з цієї проблеми див. в: N.Stehr und R. König (Hg.), Wissenschaftssoziologie (Opladen, 1975).] 
їхній об'єктивізм ${ }^{24}$. В межах цієї системи поглядів, однак, неможливо зрозуміти той факт, що історики часто зберігають розбіжності у поглядах на факти і взаємозв'язки між фактами; як і неможливо зрозуміти, чому раціональні, наукові дискусії про факти часто нагадують ірраціональні, політичні дискусії про цінності.

Другий шлях реакції з боку філософа історії на полеміку подібну до Historikerstreit - зробити висновок, що історія взагалі не є науковою дисципліною і не продукує знання. Історія у такому випадку може бути визначена (в цілому або частково) як індивідуальна «форма мистецтва», «акт віри» або «вираження культури», що не можуть бути раціонально обгрунтовані в термінах (істинних) фактичних аргументів. Подібна реакція традиційно породжується релятивістами і може бути інтерпретована як філософське дзеркальне відображення об'єктивістської реакції ${ }^{25}$. Як і об'єктивісти, релятивісти передбачають, що у справжній науці існує консенсус з приводу фактів та пояснювальних взаємовідношень між ними; оскільки ж в історії така згода відсутня, вони приходять до висновку, що історія ненаукова (в цілому або частково) і класифікують їі як «вираження культури» без претензії на істину. Цей висновок є неминучим, оскільки будь-яка претензія на знання $\epsilon$ ipso facto ${ }^{*}$ претензією на істину, як це демонструє Хемлін $^{26}$. В рамках цієї системи поглядів, однак, абсолютно незрозуміло, чому історики мають звичку обгрунтовувати свою претензію на знання, апелюючи до фактів. Якщо релятивістська точка зору на історію вірна, вони могли б із тим же успіхом зекономити свою енергію для інших цілей; точне відтворення фактів істориками настільки ж мало сприяло б якості творів історика, як це має місце у випадку з живописцями та їхніми творами. В обох випадках це не було б ні необхідною, ні достатньою умовою якості 27.

\footnotetext{
${ }^{24}$ Нольте, наприклад, подає свою тезу, що Аушвіц являв собою «реакцію» $\mathrm{i}$ «викривлену копію» винищення російської буржуазії більшовиками, як чистий «факт» («Tatsache»); Nolte Revisionismus, 23 i Vergehen der Vergangenheit, 73.

25 Див.: Novick P. Noble Dream, 3 i Bernstein Beyond Objectivism and Relativism, 18 про «картезіанську тривогу». Пропозиція Вільяма МакНіла позначати всю історіографію «міфоісторією»- оскільки в історії немає нічого абсолютно достовірного - є прикладом цієї процедури інверсії; див. його Mythistory and Other Essays (Chicago, 1986), 6-7, 19.

* В силу самого факту; тим самим (лат.).

${ }^{26}$ Hamlyn Theory of Knowledge, 95-103.

${ }^{27}$ Ця парадоксальна проблема постає перед будь-якими різновидами наративізму - розробленого як Гайденом Вайтом, так і Франком Анкерсмітом - котрі розглядають минуле як текст, представлений істориком без референційного співвіднесення з реальним минулим. Чудовий аналіз і критика Метаісторії Вайта (Балтимор,
} 
Таким чином, ані традиційний об'єктивізм, ані традиційний релятивізм, мабуть, неспроможні пояснити, чому історики вступають у дискусії на зразок Historikerstreit і апелюють до фактів, коли їхні перспективи бачення критикуються опонентами. Якщо ми хочемо розглядати історію як наукову галузь і вважаємо, що відсутність консенсусу знецінює феномен науки, тоді ми маємо спробувати знайти у філософії історії таку концепцію, яка виходить за рамки об'єктивізму і релятивізму. На мій погляд, це можна зробити, пов'язавши філософію історії з сучасною епістемологією і філософією науки - при всій повазі до постмодернізму з його неприязним ставленням до проблеми істини. Ця неприязнь породжується традиційним, але помилковим ототожненням прагнення до знання з прагненням до достовірності ${ }^{28}$. Епістемологія тут виявляється дуже корисною, тому що цей розділ філософії виявляє можливість знання, а отже, захищає від усіх різновидів скептицизму - старих і нових. Скептики, які часто розглядають історію як один зі своїх улюблених об'єктів, піддають сумніву можливість достовірного знання загалом ${ }^{29}$. Боротьба проти скептицизму, таким чином, $є$ логічною відправною точкою будь-якої філософії історії, гідної так називатись. Філософія науки - у тому числі соціальної науки - потрібна нам, тому що характерні особливості історії як дисципліни можна прояснити тільки через порівняння з іншими науками. Оскільки останні, у свою чергу, проясняються філософами, котрі ними займаються, то спеціалісти в галузі філософії історії не можуть більше дозволити собі потрапити у полон застарілих версій, тим паче що вони традиційно «позичають» поняття науки іншим дисциплінам. Оскільки філософська ідентичність історії часто формулюється шляхом її відмежування від уявлень про інші науки, існує серйозна небезпека помилок і беззмістовних протиставлень.

Що стосується епістемології і боротьби проти скептицизму, то філософія історії 1990-х років має примиритись з постмодерністськими версіями наративізму ${ }^{30}$. Що ж стосується філософії науки, філосо-

1973) і їі подальший розвиток пор.: Kansteiner $W$. Hayden White's Critique of the Writing of History // History and Theory, 32 (1993), 273-296. Kansteiner, 286, також відмічає, що позиція Вайта з проблеми референції є суперечливою. [Див. також: Zagorin J. History, the referent and narrative; Graf, Interpretation, truth and past reality, 390-397.]

${ }^{28}$ Hamlyn Theory of Knowledge, 10-16.

${ }^{29}$ Про скептицизм взагалі див.: Hamlyn Theory of Knowledge, 23-53; про скептицизм в історіï: Versions of History from Antiquity to the Enlightenment, ed. D. Kelley (New Haven, 1991), 12-13, 264-267, 502.

${ }^{30}$ [Див. мою статтю «Чи може історія бути істинною?» у книзі Jens 
фії історії варто інкорпорувати постпозитивістське бачення наукового знання ${ }^{31}$. Кінцевий висновок, до якого приводить релятивізм, відіграє потім роль відправної точки: визнання того факту, що історичне знання не має беззаперечного та єдиного фундаменту у фактах або логіці, а тому саме по собі не передбачає консенсусу. У сучасній епістемології - починаючи з «Філософських досліджень» Вітгенштайна - i сучасній філософії науки - починаючи 3 «Логіки наукового відкриття» Поппера - ця ідея веде не до епістемологічного скептицизму релятивістів, а до фалібілізму та контекстуалізму ${ }^{32}$. Контекстуалісти визнають, що будь-яке знання відноситься до конкретного епістемічного контексту. А фалібілісти визнають, що все, що претендує на те, щоб бути знанням, може бути виправленим, і має гіпотетичний характер, тому що для знання не існує жодних стійких засад - ані у відчуттях, ані у людському розумі. Відмова від «фундаменталізму», таким чином, не обов'язково призводить до епістемологічного скептицизму як бачимо, думає багато хто з постмодерністів, - але до цілком відмінної і більш конструктивної філософської позиції ${ }^{33}$. Ця позиція могла б «врятувати» істориків від скептичних наслідків постмодернізму, таких як релятивізм і суб'єктивізм відносно епістемології та етики. Допоки історики стверджують, що продукують знання, філософи історії не можуть дозволити собі неприязні до проблеми істини і до обгрунтування претензій на істину, тому що це зрештою означало б філософське самогубство.

Тому проблема обґрунтування знання не зникає. Нерозв'язна проблема фундаменту достовірного знання просто трансформується у вирішувану проблему обгрунтування претензій на знання, яке може бу-

Schröter/Antje Eddelbütel (Hgs.), Konstruktion von Wirklichkeit. Beitrage aus geschichtstheoretischer, philosophischer und theologischer Perspektive, Berlin/New York 2004.] Рекс Мартін недавно також закликав до повернення епістемології у філософію історії в роботі Objectivity and Meaning in Historical Studies: Towards a Postanalytic View // History and Theory, 32 (1993), 25-50, [див. також його: Progress in Historical Studies, in B. Fly u.a. (Hg.), History and Theory. Contemporary Readings (Oxford, 1998), 377-404].

${ }^{31}$ Див.: Callebaut $W$. Post-positivistic Views on Scientific Explanation, in L'Explication en sciences sociales: la recherche des causes en démographie, ed. J. Duchène and G. Wunsch (Brussels, 1989), 141-196; Salmon W. Four Decades of Scientific Explanation (Minneapolis, 1989).

${ }^{32}$ Історію цих обговорень див.: Bernstein Beyond Objectivism and Relativism.

${ }^{33}$ Те ж саме справедливо і по відношенню до філософії соціальних наук. Пор. аналіз скептицизму в постмодерністській антропології з боку Бомана: Bohman J. New Philosophy of Social Science: Problems of Indeterminacy (Cambridge, Mass., 1991), 103-139. 
ти помилковим. Проблема обгрунтування у філософії історії зводиться до питання: якого роду доводи використовують історики, щоб довести свої претензії на знання - або щоб спростувати такі претензії з боку опонентів - і які доводи можуть бути реконструйовані ex post facto* . Отже, «анти-фундаменталізм» зовсім не вимагає від філософів та істориків розпрощатись з епістемологією і взяти курс на «наративізм», як вважає Анкерсміт ${ }^{34}$. Я сподіваюсь показати, що існує альтернативний, більш продуктивний шлях у філософії, у відповідності з яким проблема обгрунтування не усувається, а розширюється, для того, щоб включити в себе нормативний дискурс. Цей шлях більш привабливий, адже «фактуально-нормативний» дуалістичний характер історичного дискурсу так довго турбує й істориків, і філософів історії. Цей шлях можна прояснити через аналіз комунікативної ролі мови.

Якщо філософи історії обирають цей шлях, то вони відмовляються від двох засадничих припущень щодо характеру наукового знання, які поділяються як об'єктивізмом, так і релятивізмом. По-перше, це припущення, що раціональна згода є характерною ознакою науковості; i по-друге, припущення, що раціональність науки може бути пояснена за допомогою формального методу (тобто алгоритмічно), або точного зведення формальних правил. Виходячи за рамки об'єктивізму і релятивізму, ми визнаємо наявність в науці раціональної розбіжності у думках та існування фундаментальної множинності точок зору, котрі не можна звести одну до одної ${ }^{35}$. Цей «третій шлях» у філософії історії за межами об'єктивізму і релятивізму - шлях, який ми могли б, вслід за Гіларі Патнемом, позначити як «внутрішній реалізм» ${ }^{36}$, - дозволяє проаналізувати історичну науку, уникаючи хибних дилем, породжених традиційними, але застарілими ідеями стосовно природи раціональності та науки. У контексті вказаного підходу в філософії історії можна пояснити, чому історики «все ще прагнуть трактувати історичне знання як реконструкцію, а не просто як конструкцію без

\footnotetext{
* Після доконаного факту (лат.).

${ }^{34}$ Ankersmit F.R. The Dilemma of Contemporary Anglo-Saxon Philosophy or History // History and Theory, Beiheft 25, Knowing and Telling History: The AngloSaxon Debate (1986), 27. А. Фелл у своїй статті 'Epistemological' and 'Narrativist' Philosophies of History, в Van der Dussen and Rubinoff, eds, Objectivity, 82-83, критикує Анкерсміта у тому ж відношенні.

${ }^{35}$ У сучасній філософії науки ця позиція найбільш радикально і виразно представлена П. Фейєрабендом в Against Method: Outline of an Anarchistic Theory of Knowledge (London, 1975).

${ }^{36}$ Putnam Reason, Truth and History, 49-50.
} 
будь-яких обмежень» ${ }^{37}$.

Подібно до усіх різновидів реалізму, «внутрішній реалізм» засновується на таких фундаментальних посилках: по-перше, що дійсність існує незалежно від нашого знання про неї; і по-друге, що наші наукові твердження - включаючи наші теорії - відносяться до цієї незалежно існуючої дійсності ${ }^{38}$. Зазначена реалістична інтерпретація наукового знання, котра принаймні пояснює досягнення природознавства ${ }^{39}$, стикається, однак, з двома проблемами, що виникають, якщо зіставити цю інтерпретацію з історією науки. По-перше, кореспондентна теорія істини стає проблематичною, тому що історія науки характеризується повною відсутністю спадкоємності у розвитку понять - як показав Томас Кун та інші. Через те, що відсутня така спадкоємність між поняттями, більше не можна вважати, що існує пряма відповідність між науковими твердженнями та дійсністю. По-друге, проблематичним стає звернення до наукових понять: той історичний факт, що наукові поняття змінюються у часі, не зберігаючи спадкоємності у розвитку - як це ілюструють відомі кунівські «зміни парадигм»- породжує проблему стосовно того, з якими сутностями дійсності співвідносяться наукові поняття. Згідно з реалізмом, хоча - на противагу тому, що стверджує ідеалізм - мовні сутності і можуть змінюватись, сутності дійсності вважаються інваріантними. Наративний ідеалізм Анкерсміта або лінгвістичний ідеалізм Вайта, наприклад, постулюють, що об'єкт історичної науки створюється істориком і не має референційного відношення до реального об'єкта ${ }^{40}$. Як це не парадоксально, але історія науки мо-

${ }^{37}$ Mink L.O. On the Writing and Rewriting of History $\mathrm{B}$ Mink, Historical Understanding, ed. Brian Fay, Eugene O. Golob, and Richard T. Vann (Ithaca, NY, 1987), 94.

${ }^{38}$ Leplin J. Introduction в Scientific Realism, ed. J. Leplin (Berkeley, 1984), 2; Radder $H$. Het probleem van het wetenschappelijk realisme, в Wetenschapsleer, ed. M. Korthals (Meppel/Amsterdam, 1989), 72-73.

39 Див.: Putnam H. What is Realism? в Leplin, ed., Scientific Realism, 140: «[I] типовий аргумент реалізму проти ідеалізму полягає у тому, що останній перетворює досягнення науки на чудо».

${ }^{40}$ У статті Het masker zonder gazicht: F.R. Ankesmits filosofie van de geschiedschrijving, Tijdschrift voor Geschiedenis 97 (1984), 169-195 я піддав критиці «наративний ідеалізм» Анкерсміта та його ідею самореференції історичних текстів, запропоновану в його Narrative Logic: A Semantic Analysis of the Historian's Language (The Hague, 1983). Його більш пізні ідеї я розглядаю у моїй праці: Ankersmit en het postmoderne denken over de maatschappelijke functies van de geschiedenis, в Feiten en waarden: De constructie van een onderscheid, ed. D. Pels et al. (Amsterdam, 1990), 13948. Не дивлячись на те, що наприкінці 1980-х рр. Анкерсміт відмовився від терміну «наративний ідеалізм», він не змінив своєї позиції щодо проблеми референційності; див. його The Reality Effect in the Writing of History: The Dynamics of Historiographi- 
же тому використовуватись за додатковий аргумент для інтерпретації історичного знання у «внутрішньо-реалістичний» спосіб, оскільки вона демонструє нам плинність і «непрозорість» наукових понять по відношенню до тієї дійсності, яку вони описують. Традиційно вважалось, що ця плинність є характерною ознакою саме історичних понять і тому вона використовувалась ідеалістами як аргумент на користь відокремлення історії від науки ${ }^{41}$.

Необхідно розглянути дві проблеми - кореспонденції та референційності, оскільки реалісти припускають, що можливість знання заснована на спроможності - істинних - тверджень відповідати дійсності і на спроможності - адекватних - понять співвідноситись з реальними сутностями. Слідуючи Патнему, ми можемо прояснити ці дві проблеми, інтерпретуючи кореспонденцію та референцію як поняття, значення яких є похідними від особливих понятійних каркасів, а тому релятивні по відношенню до них. Відповідно питання «Що фактично існує?» або, що є тим самим, «Що є істинним або дійсним?» завжди залежить від особливого мовного каркасу і є внутрішнім питанням по відношенню до цього мовного каркасу, в рамках якого описується дійсність. Патнем висуває наступні аргументи на користь «внутрішнього реалізму» :

Підхід, який я захищатиму, не має однозначної назви. Це пізній здобуток в історії філософії. . . Я позначу його як інтерналістсъкий підхід, оскільки його характерною особливістює той погляд, що питання «3 яких об'єктів складається світ?» є сенс ставити тільки в рамках деякої описової теорії [а theory of description]. Багато хто з філософів«інтерналістів», хоча й не всі, вважають до того ж, що існує більше ніж одна «істинна» теорія або опис світу. «Істина», згідно з інтерналістською точкою зору, - це деякий різновид (ідеалізованої) ра-

cal Topology (Amsterdam, 1989). Схожі критичні зауваження сформулював В. Велш у праці Fact and Value in History, в Facts and Values: Philosophical Reflections from Western and Non-western Perspectives, ed. M.C. Doeser et al. (The Hague, 1986), 57: «Якщо історик пише "Потім настало справжнє відродження", то не існує спостережуваного стану справ, з котрим сучасник міг би порівняти це твердження задля перевірки його істинності. На відміну від цього, твердження "Джейн Остін написала роман 'Емма"” і "Наполеон помер на острові Св. Єлени", мабуть, можна було б прийняти на основі свідчень очевидців. I хоча в цьому полягає важлива відмінність, з цього не слідує, що відродження, або щось на зразок цього, існує тільки у свідомості людини, котра стверджує, що воно мало місце». Критика аналогічної позиції Вайта міститься, наприклад, у рецензії В.Г. Дрея на книгу Вайта «Зміст форми», опублікованої у журналі History and Theory 27 (1988), стор. 284: «Хіба події стають "уявними" (знову-таки власний термін Вайта), коли їх підводять під узагальнююче поняття?».

${ }^{41}$ Цей аргумент також задіюють Вайт і Анкерсміт. 
ціональної прийнятності - свого роду ідеальна узгодженість наших переконань одне з одним та з нашим досвідом, взятим, як він представлений у нашій системі поглядів, а зовсім не у відповідності з незалежним від свідомості або від дискурсу «станом справ». Не існує точки зору всевидячого Бога, яку ми можемо знати або спроможні уявити; є тільки різноманітні точки зору дійсних людей, які відображують різні інтереси та цілі, котрим слугують їхні теорії та описи. ${ }^{42}$

Визнання того, що взаємозв'язок між мовою і дійсністю не $є$ «прозорим», призводить, відповідно, не до улюбленого висновку постмодерністів, що мова $€$ «темною» і не може відповідати дійсності та співвідноситись $з$ нею, але до набагато більш «реалістичного» висновку, що референція та кореспонденція мають інтерпретуватись як релятивні та внутрішні по відношенню до особливих понятійних каркасів ${ }^{43}$ - як відмітив Карло Гінзбург у своїй критиці постмодернізму в історії44. Той факт, що референція і кореспонденція мають інтерпретуватись відносно того чи іншого дискурсу, не може бути задіяний як аргумент проти використання цих понять взагалі, як це часто пропонується. Хоча критики кореспондентної теорії істини переконливо показали, що кореспонденція не може розумітись як критерій верифікацї̈, тобто для того, щоб контролювати істинність, кореспонденція залишається критерієм значення для істинності тверджень. Це так тому, що - як показав Вітгенштайн - знання значення деякого поняття передбачає вміння застосувати це поняття; а це в свою чергу передбачає знання тих типів речей, до яких відноситься поняття, і знання того, як ко-

\footnotetext{
42 Putnam Reason, Truth and History, 49-50; nор.: Goodman N. Ways of Worldmaking (Indianapolis, 1978), 17-20.

${ }^{43}$ Putnam Reason, Truth and History, 72-73: «Проблема... не в тому, що не існує відповідностей між словами або поняттями та іншими сутностями, а в тому, що існує забагато відповідностей. Виділяючи тільки одну відповідність між словами або мисленими знаками і незалежними від свідомості речами, ми уже повинні б мати референційний доступ до незалежних від свідомості речей». Див.: Hamlyn Theory of Knowledge, 140: «[Таким чином] розмова про факти і розмова про відповідність факту веде до деякого різновиду реалізму, не в тому сенсі, що факти тотожні з конкретним станом справ, а в тому, що необхідною умовою існування об'єктивної істини є наявність незалежно існуючого світу. Сказати, що твердження відповідає фактам, означає сказати, що це твердження узгоджується з будь-якими стандартами об'єктивної істини, котрі тут є застосовними».

${ }^{44}$ Ginzburg C. Checking the Evidence: The Judge and the Historian // Critical Inquiry, 18 (1991), 79-98. Гінзбург також критикує постмодерністську позицію як «позитивізм навпаки». Він пропонує ставитись до історичних джерел як до лінз замість того, щоб притримуватись хибної дилеми: розглядати їх в ролі прозорих осколків скла - як це відбувається у випадку «позитивізму» або в ролі глухої стіни - як це робиться у постмодернізмі. [Див. також: Ginzburg C. History, Rhetoric and Proof (Hannover und London, 1999).]
} 
ректно використовувати це поняття у твердженнях. I ми тільки тоді можемо сказати, що вірно розуміємо значення тверджень, якщо нам відомо, за яких умов вони можуть вважатися істинними, тобто коли вони відповідають факту. Якби це було не так, тобто, якби значення поняття не передбачало знання умов його істинності, компетентний носій мови не міг би виразити відмінність між, наприклад, ким-небудь, хто справді відчуває біль, і тим, хто прикидається, тобто відмінність між коректним і некоректним застосуванням цих понять. Оскільки компетентні носії мови, як правило, дійсно знають відмінність між поняттями, вони зазвичай знають і умови їхньої істинності. Помилки, які іноді при цьому робляться, не суперечать цьому факту; навпаки, поняття помилки має сенс тільки в контексті правил, а про правила можна говорити, тільки якщо їм зазвичай слідують коректним чином. Отже, той факт, що відношення кореспонденції між істинними твердженнями і світом, до якого вони відносяться, є конвенційним відношенням в рамках деякого понятійного каркаса, не усуває понять референції та істини як кореспонденції. Без цих понять, по суті, неможливо зрозуміти, про що ж ми говоримо, коли про щось говоримо ${ }^{45}$.

3 точки зору «внутрішнього реалізму» ми можемо зрозуміти, чим викликана така сильна тяга до ідеалізму в філософії історії - від Дільтея і Колінгвуда до Г. Вайта й Анкерсміта - i чому вона збиває нас $з$ вірного шляху. «Ідеалістична спокуса» завжди була заснована на аргументі, що історія як дисципліна - на противагу природничим наукам - не має справи з матеріальними об'єктами і тому їі об'єкт повинен спочатку бути побудованим у ментальний (Колінгвуд) або лінгвістичний (Вайт, Анкерсміт) спосіб і саме в сферах свідомості або мови. Оскільки в історії немає матеріального об'єкта, історики - на відміну від природознавців - не мають прямого чуттєвого доступу до своїх об'єктів ${ }^{46}$; тому історичне знання - на відміну від наукового знання не може бути заснованим на емпіричних твердженнях і не може бути інтерпретованим як знання про «реальне», а значить, є «уявним», «міфічним» тощо. Згідно з цим традиційним ідеалістичним аргументом, історія не може бути (і стати) наукою, але є формою мистецтва, формою ідеології, жанром літератури тощо.

\footnotetext{
${ }^{45}$ Hamlyn Theory of Knowledge, 53-78, 132-145, особливо с. 67 : «використання мови передбачає, що мовні вирази мають значення і це значення неможливо повністю прояснити через їх застосування або звести до нього».

${ }^{46}$ Див.: Van Fraassen B. The Scientific Image (Oxford, 1980), 13-19, одна із недавніх робіт, в якій переконливо спростовується ідея про те, що в природничих науках має місце «безпосереднє» спостереження.
} 
3 точки зору «внутрішнього реалізму», згаданий аргумент засновується на подвійному внутрішньо пов'язаному змішуванні: по-перше, змішування матеріалізму та реалізму ${ }^{47}$; і по-друге, змішування емпіризму (тобто емпіричного різновиду фундаменталізму) з науковим знанням як таким. Перше змішування знаходить своє вираження у схильності заперечувати, що нематеріальні об'єкти в деякому сенсі є реальністю i, як наслідок, схильності надавати цьому класу об'єктів виключно ментального або мовного статусу ${ }^{48}$. Передбачається, що внаслідок цієї «нереальності» твердження не можуть співвідноситись з цими об'єктами або відповідати їм, а тому вони не можуть бути істинними або хибними. Оскільки об'єкти історичних наративів - такі як феодалізм, абсолютизм, Ренесанс і т.ін. - відносяться до категорії членів цього (нематеріального) класу, історичні наративи (що складаються 3 кон'юнкцій одиничних екзистенціальних тверджень) не можуть бути істинними або хибними ${ }^{49}$. Історичні наративи, які представляють «інтерпретації, протиставляються індивідуальним одиничним екзистенціальним твердженням, що представляють «фактуальну» інформацію; тільки остання може бути істинною або хибною. Тому передбачається, що на рівні інтерпретації проблема істини не має жодного значення у філософії історії і, відповідно, (пост)модерністські філософи спрямовують свою енергію на ідеологічний, політичний, лінгвістичний або естетичний аналіз історичних наративів ${ }^{50}$.

473гідно з реалізмом - тобто епістемологічною позицією - об'єкти людського пізнання існують незалежно від суб'єкта, який пізнає. Згідно з матеріалізмом тобто метафізичною позицією - вся дійсність складається з матерії і тому існують тільки матеріальні речі.

${ }^{48}$ Див.: Faber K.-G. Theorie der Geschichtswissenschaft (Munich, 1974), 24-25.

${ }^{49}$ Невипадково Йоганн Гейзінга, на якого часто посилаються як на одного 3 інтелектуальних батьків наративізму, дотримувався іншої точки зору. У своєму есе про «естетичний характер» історичних наративів (1905) він відкрито говорить про небезпеки проєктування образів минулого, оскільки результатом цього будуть «картини, котрі є неістинними» (курсив мій). Див.: Huizinga J. Het aesthetische bestanddeel van geschiedkundige voorstellingen в Verzamelde Werken VII (The Hague, 1950), 25.

${ }^{50}$ Як Анкерсміт, так і Вайт вважають, що одиничні екзистенціальні твердження істориків дійсно відсилають до минулого і можуть бути істинними або хибними, водночас заперечуючи, що це відноситься і до кон'юнкцій таких тверджень, тобто до рівня історичної інтерпретації або наративу. Такої ж позиції дотримувались такі добре відомі релятивісти, як Бекер и Бьорд. Подібне розмежування відрізняє релятивізм від повного скептицизму, котрий заперечує можливість істинного знання усіх видів. [Див. мої статті: Kann Geschichte wahr sein? Zu den narrativen Geschichtsphilosophien von Hayden White und Frank Ankersmit в: Jens Schröter / Antje Eddelbüttel (eds.), Konstruktion von Wirklichkeit. Beiträge aus geschichtstheoretischer, 
Друге змішування - це ще один спадок грубого емпіризму. Так само як перше змішування виникло з ідеї, що «те, з чим не можна вступити у безпосередню взаємодію, не може бути реальним», друге виникає з ідеї, що «те, що не можна безпосередньо спостерігати, не можна і пізнати» і тому не може вважатись знанням ${ }^{51}$. Хоча цей аргумент давно дискредитував себе в епістемології і філософії науки, він демонструє вражаючу живучість у філософії історії - від німецьких ідеалістів через релятивізм Бекера і Бьорда до наративізму Г. Вайта та Анкерсміта ${ }^{52}$. Якщо усвідомити, що весь цей хід думки базується на

philosophischer und theologischer Perspektive, Berlin/New York 2004, 33-63, i «You got your history, I got mine». Some reflections on truth and objectivity in history, Österreichische Zeitschrift für Geschichtswissenschaften, 10(4), 1999, 563-584.]

${ }^{51}$ [Див. White H., The Modernist Event, в: Figural Realism, 66-87, особливо, 71: «Однак будь-яка спроба здійснити об'єктивний опис події або через її розчленування на множину деталей, або шляхом вбудовування її у відповідний контекст, повинна викликати два наслідки: один із них полягає у тому, що число деталей, які можна виявити у будь-якій окремій події, е безкінечно великим або, принаймні, не може бути об'єктивно визначеним. Крім того, історична подія, яка традиційно вважається такою подією, яку не тільки можна спостерігати, але і яку хтось спостерігав у минулому, за визначенням $є$ подією, яку ніхто уже не спостерігає, і отже, вона не може служити таким самим надійним об'єктом пізнання, як та, що відноситься до сучасних подій, які все ще піддаються спостереженню.»]

52 Як Вайт, так і Анкерсміт стверджують, що оскільки історичні наративи не репрезентують минулу дійсність безпосередньо, то вони ніяк не співвідносяться 3 дійсністю; тому вони є самореференційними і можуть аналізуватись виключно в ролі мовного універсуму, в котрому проблема істини зникла. Такий напрям думки являе собою лінгвістичний варіант аргументації, яку використовували Бекер і Бьорд півстоліття тому. Вони також стверджували, що оскільки історичні наративи - або «інтерпретації - не можуть бути засновані на історичній дійсності, то вони не можуть бути «об'єктивними» i, відповідно, є «уявними», заснованими на «акті віри» і суто «особистісними». Але тепер довільність і байдужість до проблеми істини зображуються як єдина альтернатива остаточному епістемологічному обгрунтуванню і всезагальному пізнавальному консенсусу. Див.: Becker $C$. What Are Historical Facts в The Philosophy of History in Our Time, ed. H. Meyerhoff (New York, 1959), 132: «Таким чином, до уявних фактів і їхнього значення додаються індивідуальні відмінності (personal equation). Історія будь-якої події ніколи не є тією ж самою для двох різних людей», і Beard C. Written History as an Act of Faith, in Meyerhoff, ed., The Philosophy of History in Our Time, 148-149: «Його віра з самого початку є впевненістю у русі історії, а його впевненість - це суб'єктивне рішення, а не чисто об'єктивне відкриття». Як релятивістські, так і наративістські доводи відображують картезіанський хід думки, що все, що не існує об'єктивно у зовнішньому світі, має тлумачитись як суб'єктивна творчість людського розуму. Див. Rorty Mirror of Nature, 342. Фундаментальна відмінність між фактами (зовнішнім) і цінностями (внутрішнім) також витікає з цього «Картезіанського спрямування» (Бернштейн).

Теоретичний аналіз і критику наративізму в філософії історії і його зв'язки 3 літературною критикою див.: Zammito J. Are We Being Theoretical Yet? The New 
помилковому ототожненні реалізму і матеріалізму, а також на застарілій епістемології, вся ідеалістична лінія аргументації починає руйнуватись. Щоб бути істинними чи хибними, (кон'юнкції) одиничних екзистенціальних тверджень не обов'язково мають вказувати на матеріальні об'єкти, як і не обов'язково цим (кон'юнкціям) фактуальних тверджень вказувати на конкретні об'єкти для того, щоб бути істинними або хибними ${ }^{53}$. І так само (кон'юнкції) цих тверджень не є неминуче «уявними», «міфічними» [«фіктивними»] або довільними, лише через те, що вони не можуть «засновуватись» на чуттєвому досвіді ${ }^{54}$. Якщо б це мало місце, то теоретичну фізику також слід було б назвати «міфічною» [або «фіктивною»] перед лицем того факту, що такі сутності, як кварки або квазари настільки ж мало «засновані» на чуттєвому досвіді, як і відродження та революціі. Оскільки історики, розмірковуючи з приводу власної дисципліни, часто запозичують ідеї у філософів, філософські помилки відносно історичної практики не є настільки вже невинними, як це зазвичай вважається.

\section{3 Внутрішній реалізм та інтерпретація історичних дебатів (debates)}

Для того, щоб показати плідність «внутрішнього реалізму» для філософії історії, я поясню деякі аспекти Historikerstreit з точки зору цього підходу, які неможливо пояснити за допомогою об'єктивізму чи релятивізму. Відправною точкою «внутрішнього реалізму» виступає та ідея, що все наше знання про дійсність опосередковане мовою; а значить, дійсність для нас - це завжди дійсність в рамках певного опису. Так, наприклад, про «Третій Рейх» ми знаємо не прямо і безпосередньо, а лише через описи істориків, заснованих на певних ключових

Historicism, the New Philosophy of History and «Practicing Historians» // Journal of Modern History, 65 (1993), 783-814. Також це роз'яснюється в Norman A.P. Telling It Like It Was: Historical Narratives on Their Own Terms // History and Theory, 30 (1991), 119-135.

${ }^{53}$ Hamlyn Theory of Knowledge, 139: «Можна говорити про якусь річ, навіть якщо ця річ не є конкретним фізичним об'єктом (наприклад, абстрактні сутності типу справедливості); подібним чином й для фактів».

${ }^{54}$ Kansteiner Hayden White's Critique of the Writing of History, 286, переконливо показує, що Вайт непослідовний у даному відношенні: «[Таким чином] проблема репрезентативної прозорості, яку випровадили через передні двері, повертається через задні». 
поняттях. Деякі історики «Третього Рейху» використовують понятійний каркас Führerdiktatur ${ }^{*}$ - німецька держава описується тоді як унікальна одноосібна диктатура; інші використовують понятійний каркас теорій фашизму або тоталітаризму - в такому разі нацистська держава описується як одна із форм фашизму чи як деякий різновид тоталітарної диктатури ${ }^{55}$. Mutatis mutandis ${ }^{*}$ те ж саме є вірним і щодо природи, тому що наші знання про неї опосередковані описами фізиків. Описи втілюють точки зору або перспективи бачення, засновуючись на яких ми спостерігаємо дійсність. Як такі, перспективи бачення належать описовій схемі [frame of description], а не самій дійсності. Це зауваження не спростовується тим фактом, що в соціально-історичній дійсності ми також стикаємося з перспективами бачення на об'єктному рівні, як це явно ілюструють статті Гілльцрубера в ході Historikerstreit. Таким чином, історики в буквальному сенсі слова розробляють, так би мовити, перспективи бачення щодо перспектив бачення ${ }^{56}$. Цей факт, тим не менш, пояснює, чому вибір перспективи бачення у соціальноісторичних науках породжує проблему «упередженості», що також можна побачити на прикладі Гілльрубера (дивись нижче).

Тому, коли ми говоримо про факти і дійсність, ми завжди маємо на увазі дійсність в рамках певної описової схеми (ось чому ми називаємо цю точку зору внутрішнім реалізмом). Це пояснює, як можливо те, що відносно одного й того самого предмету - націонал-соціалізму - різні історики продовжують посилатися на різні стани справ як на факти і продовжують посилатися на різні твердження як на істинні, а значить, як можливо те, що в історичній науці відсутня гарантія консенсусу. Цей факт пояснюється тією обставиною, що фактуальні твердження та їх істинність змінюються в залежності від їхніх описових схем. Таким чином, стає зрозумілою можливість численних і навіть несумісних істинних тверджень про «один і той самий» предмет; історики, яких таке становище спантеличує, тепер можуть бути вря-

${ }^{*}$ Диктатура фюрера (нім.).

${ }^{55}$ Пop.: Kershaw I. The Nazi Dictatorship: Problems of Perspectives and Interpretation (London, 1989), 1-42.

*3 відповідними поправками; з урахуванням відповідних відмінностей; з необхідними змінами (лат.).

${ }^{56}$ [Дослідники науки ввели в цьому контексті поняття «поняття другого порядку» (Альфред Шютц) і «подвійна герменевтика» (Ентоні Гідденс), щоб врахувати структурований за допомогою символів предмет гуманітарних наук. Загальну аргументацію цього див. в: Habermas Zur Logik der Sozialwissenschaften, 5. erw. Aufl., Frankfurt a.M. 1982.] 
товані від епістемологічної плутанини й безвиході ${ }^{57}$. Можна скористатися прикладом Нельсона Гудмена: він звернув увагу на той факт, що твердження «Сонце завжди рухається» і твердження «Сонце ніколи не рухається» обидва є істинними в залежності від точки співвіднесення [frame of reference] ${ }^{58}$. У тому ж дусі, твердження «Аушвіц був єдиним у своєму роді історичним явищем» і твердження «Аушвіц не був єдиним у своєму роді історичним явищем» також обидва можуть бути істинними в залежності від (аспектів) явищ, які порівнюються. [Однак, це не означає, що значення істинності як таке є «відносним», адже істинність завжди буде розумітися як кореспонденція між твердженнями і дійсністю. Це лише означає, що значення істинних тверджень i, відповідно, їх кореспонденція $є$ «відносною» щодо описової схеми.] Тому сам по собі факт, що істина в науці не є одноманітною і неподільною, не повинен непокоїти істориків чи підштовхувати їх до скептичних або релятивістських висновків відносно наукового статусу історії. Зрозуміло, що це не тягне за собою будь-яке твердження про конкретні претензії на істину, оскільки пояснюе лише можливість різноманітних тверджень про один і той самий об'єкт. Обгрунтованість кожної окремої претензії на істину в історичній науці повинна оцінюватися не філософами історії, а самими істориками ${ }^{59}$.

Оскільки всі твердження про факти залежать від описових схем, то твердження, відповідно до якого те чи інше є фактом, може означати лише, що розглянутий опис є адекватним. Таким чином, будучи розглянутим більш детально, фактуальне твердження являє собою не що інше, як претензію на істину. Це так, тому що поняття «істина» $\mathrm{i}$ «факт»є концептуально взаємозалежними ${ }^{60}$; тому посилаючись на факти, історики посилаються на істину. А оскільки вони обгрун-

${ }^{57}$ Прикладом може виступати голландський історик Л. де Йонг - див. його Zelfkritick в Bijdragen en Mededelingen tot de Geschiedenis der Nederlanden 105 (1990), 2, 179, 182-183, або американский історик Вільям МакНіл - див. його Мythistory (примітка 21).

${ }^{58}$ Goodman Ways of Worldmaking, 2-3.

${ }^{59}$ Відповідно до більшості коментарів Нольте і Гілльґрубера слід розглядати як таких, що програли в «Historikerstreit»: Peukert D. Wer gewann den Historikerstreit? Keine Bilanz в Vernunft riskieren: Klaus Dohanyi zum 60. Geburtstag, ed. P. Glotz et al. (Hamburg, 1988), 38-50; Kershaw I. Neue deutsche Unruhe? Der Ausland und der Streit um die deutsche Nationalund Zeitgeschichte y Streitfall Deutsche Geschichte, ed. Landeszentrale für politische Bildung NRW (Düsseldorf, 1988), 111-131.

${ }^{60}$ Hamlyn Theory of Knowledge, 135-42, особливо 135: «Насправді, якщо замислитися над тим, якими могли б бути загальні необхідні та достатні умови істинності для будь-якого твердження, то, очевидно, єдине, що могло б виступати у цій ролі, - це те, що твердження мають відповідати факту». 
товують свої претензії на адекватність «інтерпретацій», апелюючи до фактів, - що вони насправдi і роблять, як це видно навіть на прикладі такої псевдопостмодерністської дискусії, як Historikerstreit, - проблема істини не може бути знята з порядку денного жодним філософом iсторії $^{61}$. Однак фактуальні твердження ніколи не можуть бути «доведені» чи «обірунтовані» засобом дійсності, і ми можемо лише наводити аргументи на їх користь. Саме з цієї причини питання про те, що являє собою «дійсність», або про те, якими є «факти», завжди залишатиметься суперечливим. При більш детальному розгляді, висловлення фактуальних тверджень завжди означає презентацію певної описової схеми або певної перспективи бачення дійсності. Повернімося тепер до Historikerstreit і погляньмо, до яких ідей можемо ще прийти, керуючись цією філософською точкою зору.

Як Нольте, так і Гіллырубер наполягали на тому, що їхні перспективи бачення Третього Рейху - тобто їхні описові схеми - відповідають «істинній природі» націонал-соціалізму. Нольте обгрунтовував свою перспективу бачення, звертаючись до європейського, якщо не всесвітнього, характеру історії двадцятого століття, тоді як Гілльрубер відстоював свою «перспективу бачення Вермахту», звертаючись до самого Східного фронту (чи, принаймні, до цього фронту з німецького боку). 3 точки зору «внутрішнього реалізму», легко зрозуміти, чому Нольте і Гілльрубер не переконали своїх критиків. Якщо усвідомити, що образ «дійсності» завжди залежить від описової схеми а значить, від перспективи бачення, - то не буде несподіванкою, що дійсність не можна використати як аргумент на користь певної перспективи бачення, або навіть для обгрунтування її «необхідності». Це передбачає пряму відповідність між дійсністю і певним мовним каркасом - передумова, пов'язана з наївним реалізмом, але відхилена в епістемології разом з емпіризмом. Скоріше все навпаки: історик намагається встановити, що являє собою минула «дійсність», наводячи доводи на користь своєї перспективи бачення. Таким чином, саме історик, а не минуле, «диктує» історію.

Це не означає, що минуле «в дійсності» не існує або що окремі історики вільні «диктувати» будь-яку картину минулого, яку вони тільки забажають, як це, вочевидь, пропонують деякі постмодерністські мислителі. Натхненні літературною теорією наративісти, на зразок Вайта й Анкерсміта, роблять з такої пропозиції далекосяжні висновки, під-

${ }^{61}$ Див.: Zammito Are We Being Theoretical Yet?, 812: «Вірогідність і когерентність цілком необхідні для занять історією, але наукові стандарти є дисциплінарними, а не абстрактними». 
креслюючи [тотальну] автономію історичного тексту по відношенню до минулого. Їхня позиція, тим не менш, не може пояснити як можливо те, що історики часто відбраковують тексти як історично неадекватні [хіба що вони продукують прості та однозначно хибні твердження]. Такий факт із історичної практики можна зрозуміти, лише якщо припустити наявність референційного відношення між текстами істориків і дійсним минулим - оскільки без цього взаємозв'язку поняття адекватності не має сенсу - а значить, якщо не піддаватися спокусі надати історичним текстам статусу, незалежного від минулого, котре вони, як припускається, описують. Кожен, хто при написанні історї керується гаслом Дерріди - «il n'y a pas de hors texte» ${ }^{*}$, втрачає інтерес для історика саме як історик ${ }^{62}$.

Розрив референційного відношення між наративом історика і минулим як таким обгрунтовують зникненням зв'язку між історичним наративом та його фактуальною основою. Вайт, наприклад, недавно стверджував, що такі події, як вбивство Джона Ф. Кеннеді, вибух Челленджера або Голокост (bien étonnés de se trouver ensembles ${ }^{* *}$ ), слід вважати парадигмальними випадками (сучасних) історичних подій63. За Вайтом, цей тип подій відрізняє саме те, що пов'язані з ними фактуальні твердження не можуть бути обгрунтовані, і що подальші дослідження не зменшують, а збільшують неясність з приводу того, «що ж відбулося насправді». Вайт називає це «випаровуванням дійсності» або «"дереалізацією" події як такої, що, окрім усього іншого, означає або неможливість розказати єдино вірну авторитетну історію [story] про ці події, або ж можливість розказати будь-яку кількість різних історій про кожну 3 них» ${ }^{64}$. В результаті, Вайт робить висновок - за добре відомою схемою «або-або», - що коли Бог «єдино вірної авторитетної розповіді» історії вмирає, істориків охоплює хаос і свавілля: «будь-яку кількість різних історій» про минуле можна вочевидь розповісти без

\footnotetext{
*Нічого не існуе поза текстом (фр.).

${ }^{62}$ [Див.: Ginzburg History, rhetoric and proof, 1: «Розкол між методологічним розглядом і реальною історіографічною практикою рідко бував настільки різко вираженим, як в останні кілька десятиліть».]

** Здивований, що опинилися разом (фр.).

${ }^{63}$ White H. The Fact of Modernism: The Fading of the Historical Event (1993 ms.). Про розвиток поглядів Вайта та про суперечності у нього див.: Kansteiner Hayden White's Critique.

${ }^{64}$ White Fact of Modernism, 8. [The Modernist Event, 66: «Але розчинення подіі як основної одиниці буття у часі і як основного будівельного блоку історії підриває саме поняття фактуальності і тим самим ставить під загрозу розмежування реалістичного та просто уявного дискурсу. Розчинення події підриває засадничу передумову західного реалізму: протилежність між фактом і вигадкою».]
} 
будь-якого озирання на свідчення. Отже, «недовизначеність» історичного наратива з боку свідчень отримує у Вайта найбільш радикальне витлумачення. «Випаровування» межі між фактом і вигадкою, а також між історією та літературою є логічним результатом цієї примітної [скептичної] лінії міркування ${ }^{65}$.

В останніх роботах Анкерсміта ми зустрічаємося зі схожою аргументацією. Як і Вайт, він намагається розірвати взаємозв'язок між історичними наративами та їх актуальним підгрунтям. На його думку, таке відокремлення історичного наративу від свідчень найкраще ілюструє так звана «постмодерністська» чи «нова» історіографія: «Для модерніста свідчення є плитою, яку він підіймає, щоб поглянути, що під нею лежить; для постмодерніста ж - це плита, на яку він ступає, щоб перейти до інших плит: по горизонталі, а не по вертикалі» ${ }^{66}$. «Для нової історіографії текст повинен займати центральне положення - це більше не плівка, крізь яку ми дивимося (або на минулу дійсність, або на авторські наміри історика), а дещо, на що має дивитися історіограф» 67 .

Як і Вайта, Анкерсміта, вочевидь, також не хвилює той факт, що більшість істориків залишаються прихильниками «вертикального погляду» на історичне свідчення і не переймають їхнього «постулату про не-прозорість історичного тексту» в його радикальному формулюванні. Історики вчиняють так цілком обгрунтовано, оскільки якщо вони серйозно приймуть цю філософську позицію, буде зовсім незрозуміло, навіщо їм взагалі виходити із кабінету для здійснення історичного до-

65 Див. там само, 23. Ця лінія міркування тим більш примітна, що вона є суперечливою. Заперечуючи вірогідність знання про (нещодавнє) минуле - наприклад, про вбивство Дж. Ф. Кеннеді і Голокост - Вайт водночас пропонує розлогу характеристику саме цього (нещодавнього) минулого: руйнуючи поняття факту, він намагається запевнити читача у деякому факті, а саме «факті модернізму», про який він стверджує. Один пиріг двічі не з'їси.

${ }^{66}$ Ankersmit F.R. Historiography and Postmodernism // History and Theory, 28 (1989), 137-153. Досить цікаво, що Анкерсміт представляє роботу Гінзбурга The Cheese and the Worms: The Cosmos of a Sixteenth-Century Miller, trans. John and Anne Tedeschi (New York, 1982) як найкращий приклад постмодерністської історіографії, тоді як сам Гінзбург відверто ворожо налаштований до такої інтерпретації. Див. його Checking the Evidence.

${ }^{67}$ Ankersmit F.R. The Reality Effect in the Writing of History: The Dynamics of Historiographical Topology (Amsterdam, 1989), 8. Парадоксально, що Анкерсміт останнім часом відійшов від «відслідковування текстів» і запропонував аналіз «історичного досвіду» - незалежно від його мовного вираження. Див. його De historische ervaring (Groningen, 1993). Тепер, коли Вайт філософствує про історичну подію, а Анкерсміт - про історичний досвід, виникає питання, куди ще заведе нас наративізм. 
слідження. «Недовизначеність» історичних наративів з боку свідчень жодним чином не виправдовує розриву між ними. «Відсутність прозорості» говорить лише про те, що історики не можуть безпосередньо апелювати до дійсності, щоб підкріпити свої наративи, і тому повинні наводити аргументи на користь своєї реконструкції минулої дійсності - точно так, як це є вірним і для палеонтолога або геолога. У цьому процесі аргументації фактуальне свідчення відіграє вирішальну роль.

Проте, все ж, існує суттєва відмінність між історією, з одного боку, і палеонтологією та геологією, з іншого, оскільки предметом історії виступає минуле людства ${ }^{68}$. Оскільки люди проявляють інтерес до того, як їхнє минуле представлене в історіях (адже саме так утворюється індивідуальна та колективна ідентичність), вони намагаються давати оцінку залученим при цьому перспективам бачення. Як наслідок, історії можуть бути істинними, але неприйнятними, адже вони входять у суперечність з уявленням про ідентичність тієї аудиторії, для якої вони призначені. Цей практичний «інтерес» історії, підданий аналізу Юргеном Габермасом, Емілем Ангерном, Йорном Рюзеном і Гердою Нагл-Доцекал, відсутній у науках, предметом яких не є людина ${ }^{69}$. Оскільки Патнем розробляє свою концепцію «внутрішнього реалізму» тільки по відношенню до природничих наук, ми повинні поєднати цю ідею практичного інтересу історії з «внутрішнім реалізмом» для того, щоб зробити філософію історії «реалістичною». У поєднанні з мовним аналізом, ця версія «внутрішнього реалізму» здатна вивести дослідження проблеми цінностей за межі об'єктивізму і релятивізму, що я і маю намір зараз продемонструвати.

\footnotetext{
${ }^{68}$ Хоча поняття історії є онтологічно нейтральним - адже поруч з історією людства є, наприклад, історія Землі та історія вимерлих видів тварин, - у контексті цієї статті я обмежую це поняття історією людей.

${ }^{69}$ Angehrn E. Geschichte und Identität (Berlin, 1985); Rüsen J. Historische Vernunft: Grundzüge einer Historik I: Die Grundlagen der Geschichtswissenschaft (Göttingen, 1983); Nagl-Docekal H. Die Objektivität der Geschichtswissenschaft (Munich, 1982); Habermas J. Geschichtsbewusstsein und post-traditionelle Identität в Eine Art Schadensabwicklung (Frankfurt, 1987), 159-80. Короткий виклад теорії Габермаса див.: Bohman New Philosophy of Social Science, passim; короткий виклад теорії Рюзена див.: Megill A. Jörn Rüsen's Theory of Historiography between Modernism and Rhetoric of Inquiry // History and Theory, 33 (1994), 39-61.
} 


\section{4 «Внутрішній реалізм», проблема цінностей $\mathrm{i}$ Historikerstreit}

Перш ніж визначити [понятійні] рамки свого аналізу, я спочатку прокоментую саму проблему. Проблема цінностей традиційно інтерпретується в дусі Макса Вебера і його «постулату етичної нейтральності» (Wertfreiheit), хоча в цьому контексті багато хто з істориків надає перевагу цитуванню відомого положення Ранке щодо завдань, які стоять перед істориками ${ }^{70}$. Під цим постулатом Вебер розуміє методологічне правило для вчених (як вчених) не висловлювати в ході дослідження жодних ціннісних суджень, пов'язаних з досліджуваним предметом, та обмежуватись в науці твердженнями про факти. Разом з об'єктивізмом і релятивізмом Вебер був переконаний в «абсолютній різнорідності» тверджень про факти і тверджень про цінності; тому наука, як сфера фактів, має бути строго відокремлена від сфери цінностей, тобто етики, естетики і політики ${ }^{71}$. Проблема цінностей була, таким чином, розглянута Вебером на рівні одиничних екзистенціальних тверджень та одиничних оціночних суджень, а не на рівні описових схем або понятійних каркасів, тобто на рівні історичного наратива $y$ иілому. Як наслідок, найбільш важлива проблема цінностей в історіографії, пов'язана з вибором перспективи бачення, виходить за рамки традиційної системи аналізу, як я це продемонструю на прикладі $\mathrm{Hi}_{\text {- }}$ storikerstreit.

Нормативні аспекти, пов'язані з вибором перспективи бачення, найбільш важливі в історіографії, тому що історики сперечаються про них найбільше ${ }^{72}$. Це, звичайно, не означає, що взагалі не існує «проблеми цінностей» на рівні індивідуальних тверджень - вона, безумовно, існує - але тільки, що цей рівень є відносно неважливим. Як і в сфері епістемології, у сфері нормативного аналізу є необхідними «холістичний» та «лінгвістичний поворот» і з тієї ж причини: подібно до описових тверджень в історичних наративах, нормативні твердження не існують по одинці, а з'являються одне за одним, оскільки вони

\footnotetext{
${ }^{70}$ Посилання див.: Vierhaus $R$. Rankes Begriff der historischen Objektivität в Objektivität und Parteilichkeit, ed. R. Koselleck et al. (Munich, 1977), 63-77.

${ }^{71}$ Ця проблема не може бути розглянута тут в усіх ㄲï аспектах; додатковий виклад див.: Schluchter W. Wertfreiheit und Verantwortungsethik (Tübingen, 1971).

${ }^{72}$ Сучасний аналіз цієї давньої проблеми див.: Scott J. History in Crisis? The Other Side in History // American Historical Review, 94 (1989), 680-692, а також Megill A. Fragmentation and the Future of Historiography B American Historical Review, 96 (1991), 693-698.
} 
взаємопов'язані на концептуальному рівні ${ }^{73}$. Як описові твердження спираються на теорії спостереження, так і нормативні твердження завжди спираються на теорії моралі (котрі, цілком очевидно, виступають в ролі базового знання $)^{74}$.

Коли ми аналізуємо Historikerstreit з цієї точки зору, то перший факт, який слід відмітити, - це те, що Нольте і Гіллырубер наполегливо намагаються уникати дискусії з приводу проблеми цінностей, посилаючись на веберівський «постулат етичної нейтральності». Вони заперечують будь-який взаємозв'язок між підходами, втіленими в їхніх пояснюючих схемах, і приписуванням моральної відповідальності одній стороні; вони тим самим підкреслюють фундаментальну прірву між науковою історією і політикою чи етикою. Ця лінія аргументації доволі дивна, якщо пам'ятати про основний предмет суперечки: у кінцевому підсумку Historikerstreit розгорівся навколо місця Федеративної Республіки Німеччини в німецькій історії - тобто історичної ідентичності Bundesrepublik ${ }^{*}$ - а це $є$ настільки ж політичною проблемою, як і науковою. Всупереч згаданому фундаментальному факту Нольте і Гілльрубер постійно нагадують про ту нездоланну прірву, яка відокремлює їхні суто наукові дослідження від політики. Виникає враження, що в їхній об'єктивістській системі координат неможливо вбудувати ідею практичного інтересу.

\footnotetext{
${ }^{73}$ На «холістичний» і «практичний» аспекти історіографії вказує також Алан Мегілл, Recounting the Past: Description, Explanation and Narrative in Historiography // American Historical Review, 94 (1989), 3, 627-654, зокрема 647: «Врешті-решт, історик інтерпретує минуле, тобто, з необхідністю презентує минуле з точки зору деякої сучасної перспективи бачення. Ця перспектива бачення пронизує все, що пише історик». Він також підкреслює нормативний аспект, пов'язаний з вибором перспективи бачення: «Враховуючи те, що історичний твір необхідно пишеться виходячи $з$ деякої перспективи бачення, він завжди пов'язаний з нашим осмисленням історичної дійсності - навіть якщо зовні намагаються заперечувати, що такий взаємозв'язок існує. У тій мірі, в якій домінує ця зацікавленість у сучасному осмисленні, історик стає не просто істориком, але також і соціальним або інтелектуальним критиком» (647).

Той самий момент був відмічений Т. Ешплентом і А. Вілсоном в Presentcentred History and the Problem of Historical Knowledge, // Historical Journal, 31 (1988), 2, 253-274.

${ }^{74}$ Див.: MacIntyre A. After Virtue (Notre Dame, Ind., 1984) i Rundle B. Facts (London, 1993), 82-83: «Проблема корениться не в тому, що існує прірва між фактом і цінністю; скоріше, ускладнення розподіляються між фактичним і концептуальним: часто практично неможливо примирити протилежні інтереси. . » Відповідне формулювання взаємозв'язку між теорією і спостереженням див.: Goodman Ways of Worldmaking, 97: «Факти являють собою невеликі теорії, а істинні теорії - це великі факти».

* Федеративна республіка (нім.).
} 
У зв'язку з цим Гілльгрубер категорично заперечує, що його вибір на користь перспективи бачення «Вермахту» приховує у собі нормативний вибір. Він представляє цей вибір як продиктований безпосередньо історичною дійсністю. Згідно з ним, історик Східного фронту постає перед наступними альтернативами: прийняти рішення писати історію з позиції Гітлера, або з позиції росіян, або з позиції в'язнів концентраційних таборів, або з позиції німецького цивільного населення та німецької армії, що захищає його. Згідно з Гілльрубером, перші три перспективи бачення не відповідають дійсності, оскільки населення Німеччини не ідентифікувало себе з жодною із цих сторін. Тому залишається підхід з позиції німецької армії як єдино «реалістична» точка зору для історика ${ }^{75}$.

Виявити нормативні мотиви, приховані за псевдофактуальною аргументацією Гіллырубера, доволі нескладно, оскільки його спроби зняти з німецької армії і цивільного населення відповідальність за нацистські злочини достатньо незграбні. Його формулювання фактичної історичної проблеми, вочевидь, прямо взаємопов'язане з проведеним у його описовій схемі розмежуванням між (1) Гітлером, з одного боку, та німецькою армією і цивільним населенням, з іншого, та (2) німецькою армією і цивільним населенням, з одного боку, та в'язнями концентраційних таборів, з іншого. Мабуть останні - головним чином євреї, цигани, комуністи і соціалісти - не є для Гілльрубера «справжніми» німцями, оскільки вони не вважаються такими ні більшістю тодішнього німецького населення - це безсумнівний історичний факт ні (сучасним) німецьким істориком 1980-х рр. - це його нормативний вибір. Фактуальний опис Третього Рейху цим істориком зводиться у такому випадку просто до некритичного відтворення перспективи бачення дійсності «Вермахтом», включаючи його нормативне визначення «справжніх» німців і «справжньої» Німеччини ${ }^{76}$. Ця примітна точка зору виникає з очевидного ототожнення Гіллырубером (німецького) минулого з тим, що було нібито безпосередньо «спостережуваним» (німецькими) джерелами - добре відома помилка емпіриків, що не залишилось непоміченим у ході дискусії.

Розмежування, на описовому рівні, Гітлера і німецької армії дає можливість Гілльруберу характеризувати боротьбу на Східному фронті як «трагедію». Ця характеристика несе приховане нормативне наван-

${ }^{75}$ Hillgruber Zweierlei Untergang, 20-25.

${ }^{76}$ Оскільки саме Wehrmacht на практиці слугував інструментом нацистської Німеччини, фізично знищуючи її противників, позиція Гілльгрубера означає повну байдужість до їі жертв. 
таження, оскільки трагедія передбачає, що обидві сторони конфлікту можуть виправдовувати свої дії шляхом апеляції до етичних принципів; більше того, протистояння цих принципів $є$ настільки ж зрозумілим, наскільки і неминучим. Таким чином, роль Wehrmacht'y у продовженні «гітлерівської війни», навіть після того, як взимку 1942-1943 стало очевидним, що вона вже програна, легітимізується Гілльрубером через сорок п'ять років після вказаних подій. Він послідовний, коли характеризує тих німецьких військових, хто підняв повстання проти Гітлера в липні 1944 року, як «безвідповідальних» та «нереалістичних ${ }^{77}$. Як не дивно, для Гілльрубера, тим самим, історична дійсність липня 1944 року є точно такою ж, як її тлумачила (й оцінювала) більшість Wehrmacht'y, що підтримувала Гітлера, при цьому виключаються усі інші точки зору - такі як точка зору збройного опору, в'язнів таборів або росіян.

На відміну від Гілльрубера, нормативні мотиви Нольте більше замасковані псевдофактуальною зовнішньою формою його описової схеми. Найважливішим у цьому аспекті є його «фактуальне» твердження, що історіографія «Третього Рейху» до теперішнього часу була заснована на «приписуванні колективної вини»; тому ця історіографія характеризується як «моралістична» та «фактично неадекватна» і потребує «наукового перегляду». Нольте відкидає будь-яке «приписування колективної вини», оскільки ця схема аргументації бере початок від нацистів. Не дивлячись на її нарочито «інноваційний» i «науковий» характер, власна аргументація Нольте у цьому пункті страждає на серйозну неузгодженість, котра кидається в очі: він постійно критикує своїх опонентів за те, що вони засуджують його аргументи під приводом їхньої (реакційної) політичної природи, замість того, щоб робити висновок про їхню фактуальну адекватність. Згідно з Нольте, у його випадку це привело до серйозного порушення етики науки. Принаймні, це він висував як аргумент на користь використання радикальних реакційних агітаційних матеріалів у ролі історичних джерел (які ігноруються іншими істориками) для того, щоб задокументувати нацистський «страх перед більшовизмом» ${ }^{78}$. Питання історичної вини

\footnotetext{
${ }^{77}$ Hillgruber Zweierlei Untergang, 20-21.

${ }^{78}$ Nolte Vergehen der Vergangenheit, 25, 137. Нольте, тим не менше, перекручено тлумачить своїх критиків. Вони не заперечують проти того, щоб використовувати пропаганду правих політичних поглядів з метою документування умонастроїв нацистів - у цьому випадку їхнього страху перед більшовизмом, - але проти некритичного ототожнення з боку Нольте цієї пропаганди з історичною дійсністю і зведення цієї передбачуваної дійсності в ранг головної причини нацистських ма-
} 


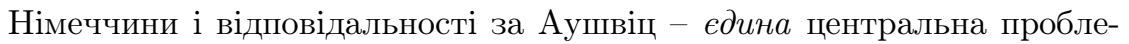
ма, з точки зору перспектив бачення його критиків, - перестає, таким чином, існувати як фактична проблема для історії і відкидається як «моралістичне» ${ }^{79}$.

Розмежування між наукою як сферою фактів і політикою як територією цінностей може, таким чином, викликати серйозні ускладнення і розбіжності в історичних дискусіях, як це явно демонструє Historikerstreit. Цей прямий зв'язок між фактуальними і нормативними судженнями коріниться у практичному інтересі історії, навіть коли це експліцитно заперечується - як це має місце з Нольте і Гілльрубером. Обидва історики здійснили спробу повернути німцям прийнятне минуле шляхом побудови менш болісної історичної ідентичності, применшуючи німецьку відповідальність за катастрофи, спричинені німцями в період між 1939 і 1945 роками. Цей безпосередній взаємозв'язок між історією та ідентичністю може пояснити, чому марно намагатись виключити етичну дискусію $з$ території істориків і чому «проблема етичного нейтралітету» історика є настільки ж давньою, як і сама історіографія ${ }^{80}$. До тих пір і у тій мірі, допоки спільноти людей будуть виводити свою ідентичність з історії, написання історії зберігає цей практичний і нормативний характер ${ }^{81}$. Тому про нормативні погляди істориків краще відкрито домовитись, як це чітко показує $\mathrm{Hi}_{\text {- }}$ storikerstreit, тим паче, якщо прийняти до відома, що у численних історичних дискусіях явні, протилежні фактуальні судження виявляються

сових убивств. Розгромну критику використання Нольте такого роду джерел див. в: Wehler Entsorgung der deutschen Vergangenheit?, 147-154 і Evans Hitler's Shadow, 84-85.

${ }^{79}$ Нольте, таким чином, ігнорує той фундаментальний факт, що коли історик описує дії індивіда або колективу як його чи їхні дії, він або вона, тим самим, приписують моральну відповідальність і конструюють ідентичність. Ця ідентичність формується не тільки навмисними діями, але також і ненавмисними наслідками дій. Той спосіб, в який реконструюються наміри, і той спосіб, в який приписуються ненавмисні наслідки, залежить як від описових, так і від нормативних міркувань; тому ідентичність одночасно виступає як фактуальним, так і нормативним поняттям. Про цю важливу характеристику історіографії див.: Angehrn, Geschichte und Identität, особливо 60-62.

80 Див.: Kelley Versions of History, 5-7.

${ }^{81}$ Як показали Рюзен і Анджерн, це відбувається через те, що поняття ідентичності одночасно є нормативним і фактуальним; див. також: Lorenz De constructie, 255-262. Енн Рігні також підкреслювала переплетення «фактуального» і нормативного дискурсів при написанні історії: Rigney A. The Rhetoric of Historical Representation: Three Narrative Histories of the French Revolution (Cambridge, 1990) і їï рецензію на роботу Ліонела Госсмана Between History and Literature в History and Theory, 31 (1992), 208-222. 
укоріненими у неявних, протилежних нормативних судженнях. Таким чином можна було б посилити раціональність історичних дискусій. Цей аргумент експліцитно формулюється ізраїльськими учасниками цієї дискусії - наприклад, такими як Саул Фрідлендер та Ден Дінер. Вони, зокрема, стверджують, що історія Третього Рейху не повинна писатись з точки зору його німецьких сучасників - як пропонував Гілльрубер, - оскільки це передбачало б повторення в історіографії їхньої моральної байдужості по відношенню до його жертв. Насилля, використовуване нацистами для того, щоб змусити замовчати своїх жертв, було б, таким чином, відновлене істориком ${ }^{82}$. Аналогічне явне звернення до відповідних нормативних принципів можна знайти в роботах Габермаса; згідно з ним, група Нольте-Гілльррубера визнає німецьку націю найвищою цінністю, у той час як їхні критики віддають першість демократії. Ця нормативна першість демократії складає основу їхньої критичної позиції по відношенню до антидемократичних традицій у німецькому національному минулому ${ }^{83}$.

У рамках «внутрішнього реалізму» - в його удосконаленій формі - $з$ цією причиною ускладнень можна відкрито розібратися і її можна пояснити у три етапи. Перший крок ілюструє відносність «прірви» між сферами фактів і цінностей. Другий крок викриває розмаїття функцій мови на основі загальної лінгвістики. Третій і останній крок вводить поняття «горизонт очікування» як сполучну ланку між фактуальним і нормативним дискурсом.

Що стосується першого кроку, то всі аргументи тут уже сформульовані. Адже ідея «абсолютної різнорідності» фактів та цінностей і заклик до «вільної від цінностей» науки історії, зрештою, засновуються на припущенні, що фактуальні судження, на відміну від ціннісних, можуть бути засновані на дійсності і супутньому припущенні, що мова в науці виконує виключно репрезентативну функцію. Тому факти і цінності ніби відокремлені одне від одного непереборною безоднею, при цьому дискусії з приводу фактів можуть бути вирішені раціональними способами, а суперечки з приводу суджень є по суті ірраціональними. Все це виводиться 3 «фундаційних» [foundational] уявлень. Те саме має місце й у випадку змалювання дискусій про фа-

\footnotetext{
${ }^{82}$ Як це викладено у статтях Дінера і Фрідлендера у збірці Ist der Nationalsozialismus Geschichte? Zur Historisierung und Historikerstreit, ed. D. Diner (Frankfurt, 1987). Див. дискусію Фрідлендера з Мартіном Брошатом: Broszat M. and Friedländer S., Um die «Historisierung des Nationalsozialismus». Eine Briefwechsel // Vierteljahrshefte zur Zeitgeschichte, 36 (1988), 339-373.

${ }^{83}$ Habermas Geschichtsbewusstsein und post-traditionelle Identität, 159-180.
} 
кти як таких, що ведуть до консенсусу, а суперечок про цінності як протилежних своїм фактуальним аналогам. Можливість обгрунтування тверджень розглядалась, тому, як гранична основа раціональності. Ці припущення поділялись як об'єктивістами, так і релятивістами ${ }^{84}$.

3 точки зору «внутрішнього реалізму», у цих дихотомій немає жодних «фундаційних» причин. Оскільки ми визнаємо, що фактуальні твердження також не можуть засновуватись на дійсності, але ми можемо тільки наводити аргументи на їх користь, то зникають будь-які апріорні «філософські гарантії» - наскільки бажані навіть у недавньому минулому, - що аргументація змусить будь-яку раціональну аудиторію, якій вона адресується, прийти до раціональної згоди. Після відмови від цього припущення «непереборна прірва» між фактуальним і нормативним дискурсом перестає бути закінченим рішенням, а стає проблемою, яку можна відкрито обговорити ${ }^{85}$. Водночас стає зрозумілим той очевидний факт, що в історичному дискурсі дуже складно

${ }^{84}$ Rorty Mirror of Nature, 341-342, 363-364; Putnam Reason, Truth and History, 143; Goodman Ways of Worldmaking, 139-140. [Bernstein, Beyond objectivism and relativism, 8: «Об'єктивізм тісно взаємопов'язаний з епістемологічним фундаменталізмом і пошуками Архімедової точки опертя. Об'єктивіст стверджує, що якщо ми не зможемо обгрунтувати філософію, знання чи мову на повноцінному науковому рівні, ми не зможемо уникнути радикального скептицизму».]

${ }^{85}$ [Див.: Rorty R. Der Spiegel der Natur. Eine Kritik der Philosophie, Frankfurt a.M. 1991: «Використання таких почесних титулів як “об'єктивний” чи "когнітивний” більше не виражає згоду дослідників один з одним (або сподівання на таку згоду)». (365) Рорті формулює тезу, що докір у «суб'єктивізмі» демонструє страх перед тим, «що в дійсності більше немає нічого проміжного між питаннями смаку і питаннями, які можна вирішити за допомогою заздалегідь сформульованих алгоритмів» (366). Putnam H. Vernunft in Wahrheit und Geschichte (Frankfurt a.M., 1982): «Насьогодні ми схиляємося до того, щоб бути занадто реалістичними [=об'єктивістськими, C.L.] по відношенню до фізики, і занадто суб'єктивістськими по відношенню до етики, й обидві ці тенденції є взаємопов'язаними. [...] Рухи у бік того, щоб бути менш реалістичним по відношенню до фізики і менш суб'єктивістським по відношенню до етики, точно так само є взаємопов'язаними» (193). Goodman N. Weisen der Welterzeugung (Frankfurt a.M., 1990): «Фундаментальні суперечки, які вирують майже у кожній науці, від психології до астрофізики, є насмішкою над занадто звеличеною претензією на консенсус між вченими» (169). Гудмен констатує, «що межа між художніми і науковими судженнями не стирається разом з межею між суб'єктивним і об'єктивним, і що будь-яке наближення до всезагальної згоди 3 приводу чого-небудь істотного є виключенням» (170). Див. далі Bundle Facts and Values в Facts, 55-85; Pels D. De «natuurlijke saamhorigheid» van feiten en waarden, в Pels and De Vries, Feiten en waarden, 14-44; Doeser M. Can the Dichotomy of Facts and Values Be Maintained?, в Doeser et al., eds, Facts and Values, 1-19; Mooij J. Feiten en waarden в De wereld der waarden [Світ цінностей] (Amsterdam, 1987), 28-45; MacIntyre A. After Virtue, 1-36; Rorty Mirror of Nature, 341-342, 363-364; Putnam Reason // Truth and History, 143; Goodman Ways of Worldmaking, 139-140. 
відокремити фактуальні суперечки від нормативних - що очевидно в Historikerstreit і в сучасній німецькій історії загалом ${ }^{86}$.

Таким чином, за межами об'єктивізму і релятивізму більше не існує самоочевидної «фундаційної» прірви між фактами і цінностями; тому згадана прірва не може використовуватись в ролі аргументу, щоб виводити нормативні виміри історіографії за рамки дискусії. Якби історики звернули увагу на «внутрішній реалізм» у філософії історії, спокуса видати нормативні судження за фактуальні твердження - як це має місце в роботах Нольте і Гілльгрубера - могла б навіть зникнути. Це значить, що нібито «більш серйозний» (фундаментальний) характер останніх виявляється ілюзорним, тому що обидва види тверджень вимагають обгрунтування за допомогою аргументації. Критикам Нольте і Гілльгрубера, мабуть, відомий цей факт, оскільки вони відкрито використовують нормативні аргументи проти своїх опонентів. Наприклад, вони стверджують, що підхід з німецької національної точки зору неприйнятний, враховуючи катастрофічні історичні наслідки німецького націоналізму для інших націй Європи. На цій підставі пропозиція Гілльгрубера переписати історію Східного фронту відхиляється. Інший приклад - відхилення ними «наукових» спроб на зразок тих, які належать Нольте і Гілльіруберу, заперечувати відповідальність Німеччини за Аушвіц за допомогою псевдофактуальної «європеїзації» німецьких масових убивств у сучасній історії ${ }^{87}$. Філософія історії, та-

\footnotetext{
${ }^{86}$ [Sabrow, Jessen u. Große Kracht (Hg.), Zeitgeschichte als Streitgeschichte.] Heщодавно я здійснив аналіз даного переплетення політичного і фактуального дискурсів у німецькій історіографії в De Sonderweg in de Duitse historiografie: Posities, problemen en discussies, [Sonderweg в німецъкій icmopioграфї̈: позиції, проблеми і обговорення] в Geschiedschrijving in de twintigste eeuw, ed. H. Beliën and G.-J.van Setten (Amsterdam, 1991), 141-181.

${ }^{87}$ [У своїй книзі Das Vergehen der Vergangenheit, 41, Нольте прямо заперечує за німцями можливість говорити про «німецьку провину»: «Усі звинувачення проти ,німців', які походять від німців, є нещирими, оскільки обвинувач не включає себе, або ж групу, до якої він належить, до числа звинувачених, і в принципі, хоче тільки нанести вирішальний удар старим ворогам». Цей різновид колективного обвинувачення є ніби «чистим зверненням звинувачення "євреїв" з боку Гітлера» (139). Чарльз Майєр у книзі Unmasterable Past, 83-84, піддав справедливій критиці аргументативну стратегію Нольте як ряд псевдо-співставлень, а саме «тез, сформульованих у вигляді псевдо-питань». Псевдо-питання «запитує не про істинність висловлювання, а про те, чи може висловлювання бути зробленим. Воно робить вигляд, що перевіряє деяку гіпотезу, але насправді, перевіряє межі прийнятного дискурсу і цілком передбачає свій ефект, адже ліберальні суспільства не люблять обмежувати дискурс». Останнє зауваження Майєра можна використовувати як додатковий аргумент на користь мого заклику піддавати в історичному дискурсі аналізу також і нормативні проблеми.]
} 
ким чином, спроможна пролити світло на зв'язки між неявними філософськими припущеннями істориків - як, наприклад, розмежування фактів і цінностей у цій суперечці - та їхнім визначенням межі легітимної наукової дискусії. При цьому вона може сприяти розширенню цих меж і відповідно підвищенню рівня раціональності ${ }^{88}$.

Другий аргумент на користь виведення аналізу проблеми цінностей за межі об'єктивізму і релятивізму можна почерпнути із сучасної лінгвістики. Разом із «внутрішнім реалізмом»-як я запропонував раніше - вона може пролити нове світло на нормативні аспекти історіографії.

Істотним для цієї аргументації є визнання того, що мова функціонує не лише як засіб репрезентації дійсності, але й також як прагматичний засіб комунікації [i, таким чином, виконує перформативну функцію] ${ }^{89}$. Усі мовні вислови [utterances] можуть також бути проаналізовані як «мовленнєві акти», як показали Остін і Серл: будь-яке використання мови - це форма соціальної взаємодії. [Парадигмальними прикладами $\epsilon$ речення на зразок «Я наказую тобі...» або «Я обіцяю тобі...». Ці речення не $є$ репрезентаціями або представленнями станів справ, але самі утворюють дію наказу та обіцянки. Промовляючи ці речення, той, хто говорить, віддає накази і робить обіцянки. Те саме вірно і по відношенню до таких перформативних актів, як оголошення війни, заключення миру, вибори, підписання договорів, одруження тощо - все, що Серл називає «інституційними фактами» ${ }^{90}$.] Відповідно використання мови є не тільки предметом синтаксичного і семантичного аналізу, але також і лінгвістичної прагматики. Будь-яка соціальна взаємодія здійснюється в контексті, який передбачає мовця - того, хто здійснює «мовленнєвий акт», - і слухача. В історії мовцями є історики, їхні тексти являють собою сукупність мовленнєвих актів, а слухачі - це та аудиторія, до якої вони звертаються. Головні функції мовленнєвих актів полягають у забезпеченні контактів і взаємовідносин, наданні інформації, вираженні емоцій, оцінюванні, у взятті зобов'язань і виконанні естетичної ролі. Традиційно філософи історії майже повністю були зайняті інформаційною функцією історичної мови, адже повістка дня критичної філософії історії диктувалась аналітичною філософією науки з їі акцентом на формальних структурах наукових пояснень. Хоча після занепаду аналітичної філософії науки в 1960-х роках філософія історії також заново відкрила оціночний та естетичний виміри історичного дискурсу, аналіз нормативних функцій мови історика залишився

\footnotetext{
${ }^{88}$ Це також є метою програми Рюзена; пор. його Historische Vernunft.

${ }^{89}$ Dik S. and Kooij J. Algemene Taalwetenschap (Utrecht, 1991), 20-39.

${ }^{90}$ [Searle J. Die Konstruktion gesellschaftlicher Wirklichkeit (Reinbek, 1997), 41-68.]
} 
дещо рудиментарним ${ }^{91}$. Відсутність уваги до цих аспектів коріниться в об'єктивізмі і релятивізмі, адже вони обидва передбачають, що нормативна функція мови виключає репрезентативну функцію як наслідок нібито «непереборної прірви» між судженнями про факт і судженнями про цінності. Нормативний вимір історичного дискурсу тому зазвичай визначався в історичному дискурсі як «проблема етичного нейтралітету». Вирішення цієї проблеми передбачалось знайти, головним чином, на основі принципів емпіризму, тобто «визволивши розум» від усіх факторів, що заважають отриманню істинного знання. Це зводиться до усунення усіх беконівських ідолів, тобто усіх ідеологічних - оціночних - впливів. Хоча більшість істориків сумнівається у тому, чи може цей процес бути завершеним, це вважається практичною, а не фундаментальною проблемою. Нормативні функції мови історика, таким чином, представляються як загроза для репрезентативної функції.

Це «придушення» нормативної функції мови коріниться в емпіризмі з його чітким розмежуванням фактів і цінностей та його основоположною парадигмою наукового знання. Як це не парадоксально, але емпіризм навіть збиває з істинного шляху ті напрямки у філософії історії, котрі експліцитно ставлять своїм завданням «подолання» емпіризму - подібно до різновиду наративізму, який розвиває Гайден Вайт, - тому що позначення усіх форм історіографії як «ідеологічних» є у цьому відношенні простим оберненням емпіризму ${ }^{92}$. Та версія «внутрішнього реалізму», яку я відстоюю, спроможна уникнути безплідної дилеми «наука проти ідеології», оскільки вона визнає, що мова історика може одночасно виконувати як репрезентативну, так і нормативну функції (і саме це має місце, коли ми встановлюємо якусь ідентичність $)^{93}$. Завдяки своєму «холістичному» характеру «внутрішній реалізм» без жодних проблем визнає, що одне $i$ mе саме твердження може одночасно виконувати різні функції 94 . Твердження, які здаються

${ }^{91}$ Короткий опис занепаду аналітичної філософії науки див. у Salmon Four Decades of Scientific Explanation. Короткий опис занепаду аналітичної філософіï історії див. у Ankersmit F.R. De navel van de geschiedenis: Over interpretatie, representatie en historische realiteit (Groningen, 1990), 23-43.

92 [Див. мою статтю: Kann Geschichte wahr sein? Zu den narrativen Geschichtsphilosophien von Hayden White und Frank Ankersmit в Jens Schröter/Antje Eddelbüttel (eds.), Konstruktion von Wirklichkeit. Beiträge aus geschichtstheoretischer, philosophischer und theologischer Perspektive, Berlin/New York 2004, 33-63.]

${ }^{93}$ Rüsen Historische Vernunft, 78: «Ідентичність, котра стає предметом обговорення у процесі розказування історій, не є незмінним фактом. Хто ми є, залежить і від того, ким нам дозволяють бути інші і ким ми самі хочемо бути по відношенню до інших».

${ }^{94}$ Mooij Feiten en waarden, 28-44. 
описовими, наприклад, «Фон Штауфенберг був справжнім німецьким офіцером», «Адольф Гітлер був австрійським негідником» або «Битва на Східному фронті була трагедією» також можуть бути проінтерпретовані як нормативні твердження ${ }^{95}$. [Задіяні тут метафори виражають як когнітивні, так і нормативні погляди - що підкреслюється і представниками сучасного дискурс-аналізу, наприклад, Ф. Сарасіном ${ }^{96}$.]

Тому «фундаментальну відмінність» між судженнями про факти і судженнями про цінності більше не можна вважати чимось само собою зрозумілим і більше не можна використовувати в ролі аргументу для обмеження рамок історичної дискусіі. [Так, у багатьох національних історіях зустрічаються метафори «землі обітованої», «нереалізованої нації» або інші уявлення про особливе «національне призначення», які можуть і мають розглядатися як мовленнєві акти обіцянки - йдеться цілком очевидно про деякий нормативний акт, який видає себе за опис фактів, або обіцянку, що тягне за собою моральне зобов'язання її виконання ${ }^{97}$.] «Ціннісна навантаженість» і «по самій своїй суті суперечливий характер» соціально-історичних понять ${ }^{98}$ - ті аспекти історіогра-

95 Див.: Bundle Facts, 66-67.

${ }^{96}$ [Ф. Сарасін у своїй книзі Geschichtswissenschaft und Diskursanalyse (Frankfurt a.M., 2003), зокрема, на стор. 91-231, відстоює тезу, що використання бактеріологічних метафор у дискурсі про нації та суспільства - розмови про організми, в які проникають чужорідні і шкідливі паразити і які, для забезпечення свого виживання, ведуть оборонні війни проти цих вторгнень, - полегшили геноцидні практики XX століття: «У 20-му столітті політичний дискурс був у буквальному сенсі "отруєний" метафорами, що експлуатують тему "інфікованого організму" - тобто, метафорами забруднення "народного організму" або ж "грунту" різноманітними мікробами, паразитами і тому подібним. Такі мовні форми принаймні сприяли певного роду діям - і не варто забувати, що люди, які у такий спосіб оголошувались "шкідниками", умирали потім в Аушвіці в “дезінфекційних камерах"» (194). Таким чином метафоричний опис меншин, таких як євреї і цигани, був пов'язаний із нормативним закликом позбавитися від них. Примітно, що розумне відстоювання Сарасіном дискурс-аналізу супроводжується нерозумінням ним таких критиків «лінгвістичного повороту» в історії, як Георг Іггерс, Ричард Еванс і Роже Шартьє. Сарасін також ототожнює наївний реалізм з реалізмом загалом та істину як кореспонденцію із взаємно-однозначною відповідністю між твердженнями і дійсністю, коли він пише, що дискурс-аналіз, на відміну від «реалістичної» історіографії, «більше не може плекати ілюзій щодо достовірності того, що його твердження знаходяться в обов'язковому і тим самим єдино істинному відношенні відповідності 3 “фактами"» (9). Див. також його критику Маслоу на стор. 57.]

97 [Перформативний характер історичних текстів розглянув Квентін Скуннер в своїй книзі Visions of Politics, Vol. I: Regarding Method (Cambridge, 2002).]

${ }^{98}$ Gallie $W$. Essentially Contested Concepts в Proceedings of the Aristotelian Society 1955-1956 (London, 1957), 167-198. [особливо, 193: «Визнання того, що це поняття $є$ дуже спірним, передбачає визнання його альтернативного використання (такого, що відкидає самого себе) як не тільки логічно можливого і по-людськи "зрозуміло- 
фії, які частіше відмічались, ніж аналізувались, - можна таким чином пояснити, уникаючи Сцилли «вільного від цінностей» об'єктивізму і Харибди «ідеологічного» релятивізму.

Третій і останній крок у напрямку виведення аналізу проблеми цінностей в історіографії за межі об'єктивізму і релятивізму полягає у тому, щоб у ході аналізу історичної суперечки ввести поняття «горизонт очікування» (Erwartungshorizont $)^{99}$. Це поняття допомагає пояснити, як різноманітні нормативні концепції пов'язані з різноманітними описами історичної дійсності, тому що воно може функціонувати у ролі моста між «основними припущеннями» 100 істориків та їхньою аудиторією. Ці основні припущення, що мають свої джерела у [різних] соціальних онтологіях, [«стилях мислення» чи «протоідеях»] є частиною політичних ідеологій; тому доречно говорити про «ліберальну», «консервативну» та «марксистську» традиції в історіографії і пов'язувати історіографічні суперечки з політико-ідеологічною боротьбою «світоглядів» ${ }^{101}$. [У цьому відношенні Гайден Вайт був правий у своїй Метаісторії.]

Щоб пояснити «горизонт очікування» і встановити здійснюваний ним вплив, ми спочатку маємо ближче познайомитись з тими способами, за допомогою яких історики обгрунтовують свої претензії на знання. Процес обгрунтування істориками своїх тверджень традиційно розподіляється на фазу фактуального дослідження і фазу інтерпретації та пояснення. Факти зазвичай оцінюються на основі логічно обгрунтованих аргументів, з урахуванням відносної міри їх підкріпленості джерелами; інтерпретативні і пояснюючі твердження, як правило, оцінюються на основі порівняльних аргументів, виходячи з інтерпретативного і пояснюючого потенціалу ключових понять ${ }^{102}$. Основна

го", але й як незмінної критичної оцінки власного використання чи інтерпретації спірного поняття. ... Отже, одним із цілком бажаних наслідків визнання цієї суттєвої суперечливості очікувано може бути помітне зростання рівня аргументів у дискусіях між сторонами, що опонують одна одній. I це означало б prima facie виправдання такого, що триває, суперництва між різними сторонами, що змагаються за підтримку і визнання своєї позиції».]

${ }^{99}$ Подальший аналіз цього поняття див.: Thompson $M$. Reception Theory and the Interpretation of Historical Meaning // History and Theory, 32 (1993), 248-273.

100 Див.: Gouldner A. The Coming Crisis of Western Sociology (London, 1970), 30-31. 101 [Про соціальні онтології див.: James S. The Content of Social Explanation (Cambridge, 1984). Залучаються, наприклад, різні поняття соціальної причинності. Про «стилі мислення» і «протоідеї» (Людвік Флек) пор.: Sarasin Geschichtswissenschaft und Diskursanalyse, 196-199.]

${ }^{102}$ На цьому етапі корисно розрізняти проблемно-орієнтований тип історії (histoire problème), котра намагається знайти пояснення конкретним і ясно викладеним 
стратегія на цій фазі - усунення конкуруючих аргументів 103 .

Як це парадигмальним чином можна бачити на прикладі суперечок на зразок Historikerstreit, аргументи на обох фазах не є автоматично «раціонально очевидними» і не приводять автоматично до згоди ${ }^{104}$. Жодний заклик до «єдино вірного історичного методу» не може приховати цей факт ${ }^{105}$. Поняття «горизонт очікування» допомагає виявити один аспект цієї відсутності консенсусу - а тому і плюралізму в історіографії, оскільки воно робить нас знаючими, що історики не реконструюють минуле у вакуумі, а з урахуванням певної аудиторії; тому велика кількість точок зору в історіографії може також бути пояснена виходячи зі споживацького боку історіографії - професійної і непрофесійної. Таким чином, хоча усі «наукові» історики пов'язані «правилом дійсності», вони водночас пов'язані тим, що може бути позначеним як «правило аудиторіі» ${ }^{106}$. Це останнє правило може допомогти нам пояснити, яким чином істориками використовується «наративний простір»: це допомагає пояснити, які з усіх можливих істинних історій також визнаються такими. Це зовсім не тривіально, адже історики, так само як і представники природничих наук, прагнуть не до істини самої по собі, і не до повної істини, а лише до релевантної істини $^{107}$. Оскільки історичні джерела безпосередньо не «диктують» спосіб реконструкції минулого, вони завжди пропонують наративний

гіпотезам, та інтерпретативний тип історії, яка намагається надати всеосяжні і наочні інтерпретації (histoire total). Базова стратегія першого типу полягає в усуненні конкуруючих пояснень, в основі другого типу - демонстрація того, що певні поняття спроможні поєднувати розрізнені факти в осмислене ціле. У вкрай вже заповнених нішах історіографії, як правило, діють через усунення опонентів. Про використання істориками свідчень див.: Kosso P. Historical Evidence and Epistemic Justification: Thucydides as a Case Study // History and Theory, 32 (1993), 1-14.

103 Див. Martin The Past Within Us, 30-85.

${ }^{104} \mathrm{He}$ дивлячись на те, що фактичні доводи оцінюються іншими істориками на основі критерію несуперечливості - несуперечливості з інформацією, отриманою з джерел і ними підтвердженою, - цей критерій сам по собі не гарантує консенсусу. Ця відсутність консенсусу має дві причини на рівні джерел: не тільки можливість для різних істориків досліджувати «один і той самий» об'єкт - наприклад, Третій Рейх чи Голокост, - використовуючи різні джерела, але також і можливість для різних істориків інтерпретувати одні і ті самі джерела по-різному - як це мало місце у випадку з Нольте та інтерпретацією реакційної пропаганди.

105 Аналіз та історію розвитку концепції «історичного методу» див.: Historische Methode, ed. C. Meier and J. Rüsen (Munich, 1988), зокрема, статті Й. Рюзена, Е. Топольськи і Й. Мерана.

${ }^{106}$ [Роль аудиторії, звичайно ж, аналізувалась уже в класичній риториці. У цьому відношенні і «наукова» історія повинна підкоритися риториці.]

107 Див.: Goodman Ways of Worldmaking, 18. 
простір для декількох пояснюючих описів (це залишається раціональним зерном Meтаicmopï Вайта). Які з цих описів є апріорно правдоподібними, це змінюється не тільки разом зі зміною пізнавальних очікувань, але також і разом зі зміною нормативних очікувань аудиторії, до якої звертається історик. Остання особливість добре відображена в історії історіографії, особливо в «гарячих» суперечках подібних до Historikerstreit або «полеміки навколо Фішера» [чи «полеміки навколо Гольдхагена»] $]^{108}$.

Пізнавальні очікування встановлюють межу для такого типу факторів, які можуть бути представлені як причинні фактори як, наприклад, окремі умонастрої (як у Нольте) на противагу надіндивідуальним, колективним факторам (як у Моммзена) ${ }^{109}$. Нормативні очікування обмежують конкретний вибір факторів - наприклад, окремих людей і спільнот, - які можуть бути відібрані як причинні фактори. Цей нормативний вибір, як показав Дрей, безпосередньо пов'язаний з приписуванням відповідальності та вини ${ }^{110}$. Конкретним прикладом цього слугує національна приналежність «героїв і негідників» у національних історіях (навіть коли ці національні історії маскуються під порівняльні, міжнародні історії). Тому зовсім невипадково, що консервативна група Нольте-Гіллырубера вважає радянського диктатора Сталіна зрештою відповідальним за злочини свого

\footnotetext{
${ }^{108}$ Про «полеміку навколо Фішера» див.: Sywottek A. Die Fischer-Kontroverse: Ein Beitrag zur Entwicklung des politisch-historischen Bewusstseins in der Bundesrepublik в Deutschland in der Weltpolitik des 19. und 20. Jahrhunderts, ed. I. Geiss and B.J. Wendt (Düsseldorf, 1974), 19-46. [Sabrow, Jessen und Große Kracht (Hg.), Zeitgeschichte als Streitgeschichte. Про полеміку навколо Гольдхагена див. мій аналіз в Model murderers. Afterthoughts on the Goldhagen method and history // Rethinking History 6, 2 (2002), 131-151.]

1093вичайно, описовий і пояснюючий рівні концептуально переплетені, але все ж доцільно розмежовувати їх аналітично, оскільки відповідь на питання «що» не обумовлює відповіді на питання «чому»; пор.: Martin R. On Dray's 'Conflicting Interpretations' в Hermeneutics: Questions and Prospects, ed. G. Shapiro et al. (Amherst, 1984), 262: «Характеристика події, котра підлягає поясненню, визначає рівень і встановлює обмеження щодо того, що буде вважатися поясненням». Стосовно філософських доводів пор.: James Social Explanation, passim; про історичні доводи див., наприклад, дискусію про роль Гітлера в історії Німеччини: Broszat $M$. Nach Hitler: Der schwierige Umgang mit unserer geschichte (Munich, 1988), зокрема 11-33, 119-131 і 227-234; Mommsen H. Der Nationalsozialismus und die deutsche Gesellschaft (Hamburg, 1991), особливо 67-102 і 184-233. Щодо дискусії про роль особистості в історії див.: Lorenz C. et al., Het historisch atelier: Controversen over causaliteit en contingentie in de geschiedenis (Amsterdam/Meppel, 1990).

${ }^{110}$ Dray W.H. Philosophy of History (Englewood Cliffs, NJ, 1964), 21-41. Пор. Pompa $L$. Value and History в van der Dussen and Rubinoff, eds, Objectivity, 112-132 додаткові посилання і обговорення.
} 
німецького «близнюка» в політиці, Адольфа Гітлера. Цей хід думок включаючи ідею, що в 1941 році Гітлер почав війну на Сході тільки щоб попередити війну Сталіна, заплановану на 1942 рік, - вже глибоко укорінився в консервативних колах у Федеративній Республіці Німеччини $^{111}$. Так само невипадково те, що їхні критики категорично відкидали цей історіографічний «експорт» німецької історичної відповідальності, оскільки у ліберальних і лівих колах Федеративної Республіки було дуже поширене переконання, що німцям необхідно «виправити» їхне нацистське минуле (Aufarbeitung der Vergangenheit). Історики враховують ці «горизонти очікування» тому, що вони значно різняться і в деякій мірі визначають сприйняття історичних досліджень. Ілюстрацією цього факту є те, що два табори в Historikerstreit друкували свої праці у виданнях, що значно відрізняються за своїм політичним забарвленням, і таким чином, адресованих дуже різним аудиторіям. Головна особливість Historikerstreit, у порівнянні з іншими історичними суперечками, полягала тільки у тому, що ці горизонти очікувань були набагато більш очевидними, аніж зазвичай.

\section{5 Висновок}

У цьому нарисі я стверджував, що завдання філософії історії- прояснити практику історії; тому філософія історії повинна аналізувати результати роботи істориків і їхні суперечки - включаючи припущення, що ними приймаються. Вона має прояснити той факт, що історики здійснюють реконструкцію минулої дійсності на основі фактуального дослідження і обговорюють адекватність цих реконструкцій; водночас вона має прояснити той факт, що ці дискусії рідко приводять до консенсусу і що, відповідно, найбільш істотною характеристикою історії як дисципліни є плюралізм.

111 Див.: Evans Hitler's Shadow, 138: «Те, як люди ставляться до Третього Рейху і його злодіянь, дає ключ до розуміння того, як вони могли б використовувати політичну владу зараз і в майбутньому. Ось чому неоконсервативна реінтерпретація німецького минулого є такою тривожною. Адже багато, якщо не більшість, доказів витягаються, свідомо чи несвідомо, із самої нацистської пропаганди»; Maier, Unmasterable Past, 64: «Позиція Нольте-Феста надала наукового статусу тому, що до цього являло собою маргінальний дискурс Soldatenzeizung або асоціації колишніх есесівців». Недавній огляд див.: Lüdtke A. «Coming to Terms with the Past»: Illusions of Remembering, Ways of Forgetting Nazism in West Germany // Journal of Modern History, 65 (1993), 542-572, [і мою статтю Bordercrossings]. 
Аналіз Historikerstreit показує, що традиційні об'єктивізм і релятивізм не можуть пояснити, чому історики постійно дискутують між собою; цей аналіз також показує, що нечітке розрізнення між судженнями про факти і судженнями про цінності здійснює сильний вплив на ці суперечки, тому що судження про цінності вважаються такими, що виходять за межі раціональної дискусії. Це розрізнення базується на застарілих припущеннях з приводу раціональності науки, що поділяються об'єктивізмом і релятивізмом. Внутрішній реалізм виходить за межі об'єктивізму і релятивізму в історіографії, хоча для того, щоб перенести «внутрішній реалізм» зі сфери філософії природничих наук - де він був сформульований Гіларі Патнемом - в історію, було введено поняття практичного інтересу історії. За допомогою зазначеного поняття і передбачуваного ним поняття ідентичності можна виявити нормативні корені плюралізму в історіографії. По-друге, аналіз розрізнення між фактами і цінностями виявляє ці корені в об'єктивізмі і релятивізмі; тому його необхідно піддати новому аналізу з точки зору «внутрішнього реалізму». Цей аналіз, застосований на прикладі $\mathrm{Hi}$ storikerstreit, демонструє відносність такого розрізнення і незадовільний характер спроб прояснити нормативні виміри історії: аргументи на користь усунення нормативної дискусії із легітимної наукової суперечки є необгрунтованими і застарілими. По-третє, щоб дати більш адекватне пояснення нормативних аспектів історіографії, 3 «внутрішнім реалізмом» можна пов'язати теорію «мовленнєвих актів» і поняття «горизонт очікувань». По-четверте, історики можуть отримати користь від «внутрішнього реалізму», оскільки рамки їхніх дискусій були б розширені за рахунок включення традиційно прихованих нормативних питань, котрі до них залучаються. Таким чином, хоча філософи історії використовують твори і суперечки істориків як відправну точку і первинний матеріал для аналізу, філософія історії зовсім не займається простим відтворенням поглядів істориків на їхню професію.

Ця інтерпретація завдань філософії, на мій погляд, необхідна для того, щоб зберегти зв'язок між філософією історії та історією, а також, щоб попередити виродження філософського аналізу у «формалістичні пухлини, які постійно ростуть, живлячись своїми власними соками» ${ }^{112}$. «Внутрішній реалізм» у його виправленій формі пропонує

${ }^{112}$ Фейєрабенд використовує цю фразу для характеристики розвитку філософії науки; див.: Feyerabend P. Philosophy of Science: A Subject with a Great Past в Minnesota Studies in the Philosophy of Science, ed. R. Stuewer (Minneapolis, 1970), V, 183. 
як історикам, так і філософам історії «реалістичний» шлях виходу за межі об'єктивізму і релятивізму, уникаючи при цьому помилок наративізму, котрий оминає трясовину позитивізму, але потрапляє до сипучих пісків постмодернізму ${ }^{113}$. Самі історики стверджують, що відображують минуле і таким чином підпорядковуються «правилу дійсності»; тому, сам по собі факт, що ми пізнаємо минуле тільки через описові схеми, не приводить до висновку, що минуле є описом або може вважатися таким ${ }^{114}$.

Переклад з англ. О.В. Мішалової та О.П. Панафідіної.

Надійшла до редакцї̈ 15 серпня 2020 р.

doi) 10.31812 /apd.v0i21.3888

113 [Цей аргумент я розвинув у своїй статті Kann Geschichte wahr sein? Zu den narrativen Geschichtsphilosophien von Hayden White und Frank Ankersmit в Jens Schröter/Antje Eddelbüttel (eds.), Konstruktion von Wirklichkeit. Beiträge aus geschichtstheoretischer, philosophischer und theologischer Perspektive, Berlin/New York 2004, 33-63.]

${ }^{114}$ Порівняйте критику «пан-текстуалізму», здійснену Замміто, і «внутрішньотекстовий нарцисизм» «нової» філософії історії з ï повним розчиненням референційності історичних наративів в Are We Being Theoretical Yet? [i схожу критику Загоріна в його праці Narrative, history, and the referent.] 